\title{
Strategic Need for a Multi-Purpose Thermal Hydraulic Loop for Support of Advanced Reactor Technologies
}

James E. O'Brien, Piyush Sabharwall, Su-Jong Yoon, Gregory K. Housley

September 2014

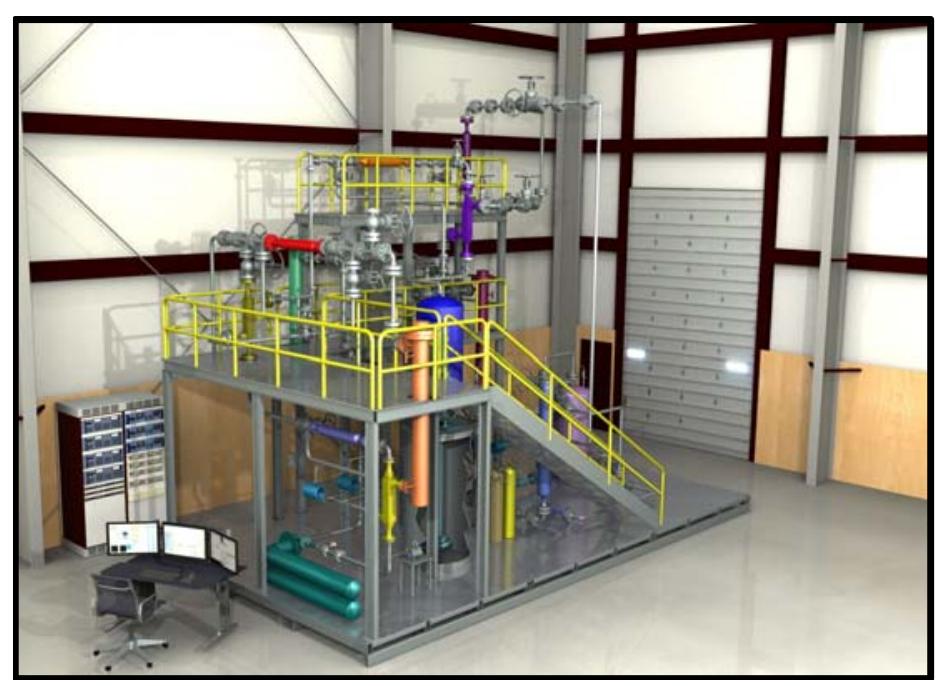

The INL is a U.S. Department of Energy National Laboratory operated by Battelle Energy Alliance 


\section{DISCLAIMER}

This information was prepared as an account of work sponsored by an agency of the U.S. Government. Neither the U.S. Government nor any agency thereof, nor any of their employees, makes any warranty, expressed or implied, or assumes any legal liability or responsibility for the accuracy, completeness, or usefulness, of any information, apparatus, product, or process disclosed, or represents that its use would not infringe privately owned rights. References herein to any specific commercial product, process, or service by trade name, trade mark, manufacturer, or otherwise, does not necessarily constitute or imply its endorsement, recommendation, or favoring by the U.S. Government or any agency thereof. The views and opinions of authors expressed herein do not necessarily state or reflect those of the U.S. Government or any agency thereof. 
INL/EXT-14-33300

Revision 0

\section{Strategic Need for a Multi-Purpose Thermal Hydraulic Loop for Support of Advanced Reactor Technologies}

James E. O'Brien, Piyush Sabharwall, Su-Jong Yoon, Gregory K. Housley

September 2014

Idaho National Laboratory

Nuclear Science and Technology

Idaho Falls, Idaho 83415

http://www.inl.gov

Prepared for the

U.S. Department of Energy

Under DOE Idaho Operations Office

Contract DE-AC07-05ID14517 

Nuclear Science and Technology

Strategic Need for a Multi-Purpose Thermal Hydraulic Loop for Support of Advanced Reactor Technologies

INL/EXT-14-33300

Revision 0

September 2014

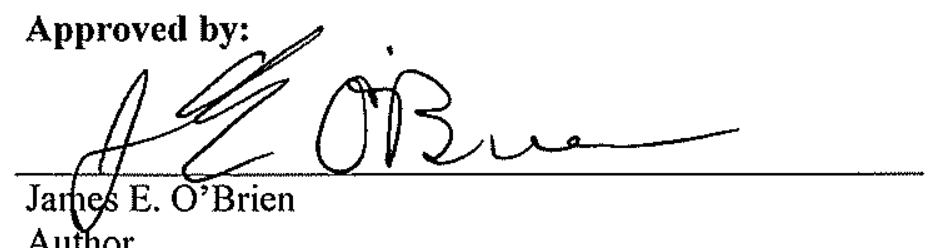

Author

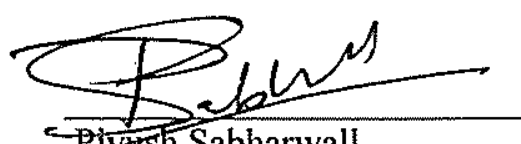

Pyotr Sabharwall Reviewer

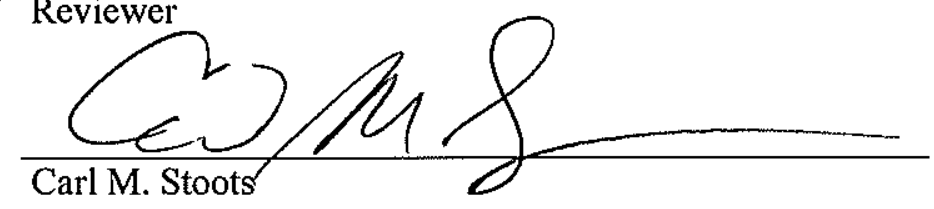

Approver

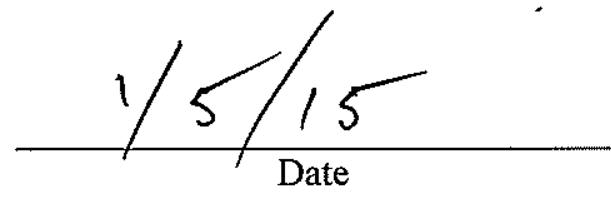

$1 / 5 / 15$

Date

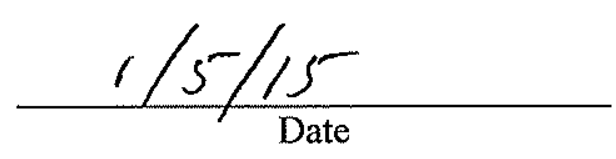





\section{EXECUTIVE SUMMARY}

This report presents a conceptual design for a new high-temperature, multi-fluid, multi-loop test facility for Idaho National Laboratory (INL) to support thermal hydraulic, materials, and thermal energy storage research for nuclear and nuclear-hybrid applications. In its initial configuration, the facility will include a high-temperature helium loop, a liquid salt loop, and a hot water/steam loop. The three loops will be thermally coupled through an intermediate heat exchanger (IHX) and a secondary heat exchanger (SHX).

Research topics to be addressed with this facility include the characterization and performance evaluation of candidate compact heat exchangers such as printed circuit heat exchangers (PCHEs) at prototypical operating conditions, flow and heat transfer issues related to core thermal hydraulics in advanced helium-cooled and salt-cooled reactors, and evaluation of corrosion behavior of new cladding materials and accident-tolerant fuels for light water reactors (LWRs) at prototypical conditions. Based on its relevance to advanced reactor systems, the new facility has been named the Advanced Reactor Technology Integral System Test (ARTIST) facility. Research performed in this facility will advance the state of the art and technology readiness level of high-temperature IHXs for nuclear applications, while establishing INL as a center of excellence for development and certification of this technology. The thermal energy storage capability will support research and demonstration activities related to process heat delivery for a variety of hybrid energy systems and grid stabilization strategies. Experimental results obtained from this research will assist in development of reliable predictive models for thermal-hydraulic design and safety codes over the range of expected advanced reactor operating conditions. Proposed/existing IHX heat transfer and friction correlations and criteria will be assessed with information on materials compatibility and instrumentation needs. The experimental database will guide development of appropriate predictive methods and be available for code verification and validation $(\mathrm{V} \& \mathrm{~V})$ related to these systems. 


\section{ACKNOWLEDGMENTS}

The authors would like to acknowledge the Laboratory Directed Research and Development Program of the Nuclear System Design and Analysis Division for supporting the development of the advanced reactor technology multi-purpose thermal hydraulic loop.

This report was prepared as an account of work sponsored by an agency of the United States Government. Neither the United States Government nor any agency thereof, nor any of their employees, makes any warranty, express or implied, or assumes any legal liability or responsibility for the accuracy, completeness, or usefulness of any information, apparatus, product, or process disclosed, or represents that its use would not infringe privately owned rights. Reference herein to any specific commercial product, process, or service by trade name, trademark, manufacturer, or otherwise, does not necessarily constitute or imply its endorsement, recommendation, or favoring by the United States Government or any agency thereof. The views and opinions of authors expressed herein do not necessarily state or reflect those of the United States Government or any agency thereof. 


\section{CONTENTS}

EXECUTIVE SUMMARY vii

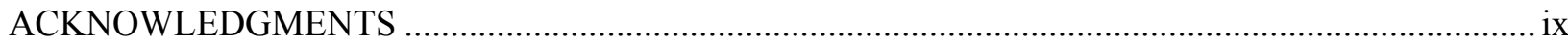

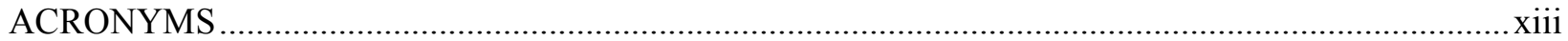

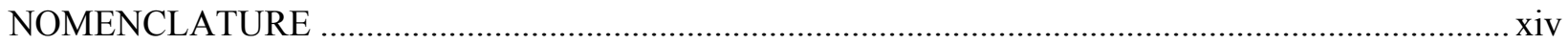

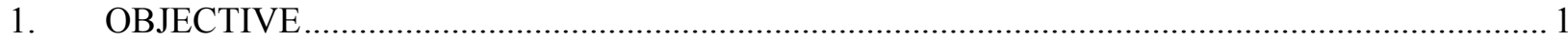

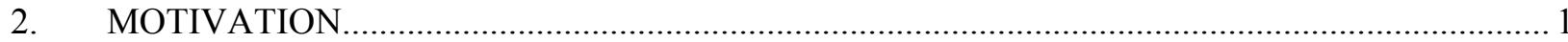

3. PRELIMINARY DESIGN OF THE MULTI-PURPOSE THERMAL HYDRAULIC

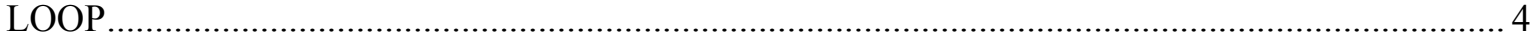

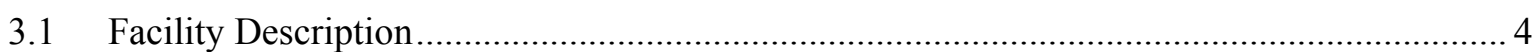

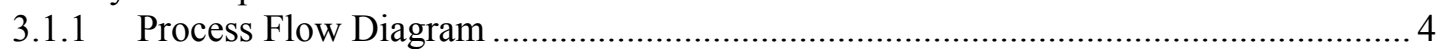

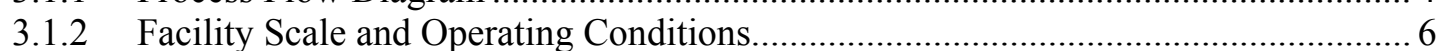

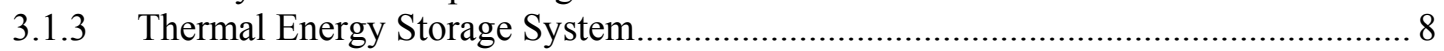

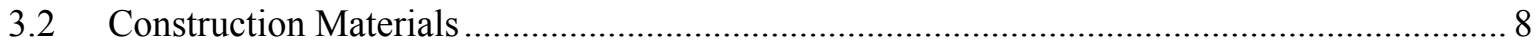

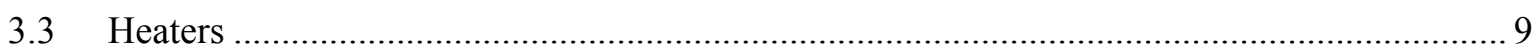

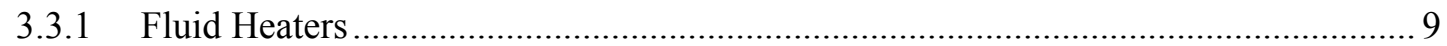

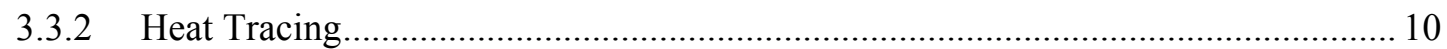

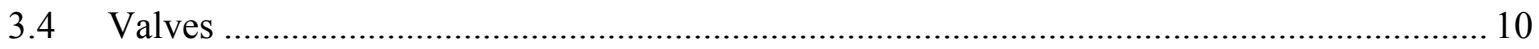

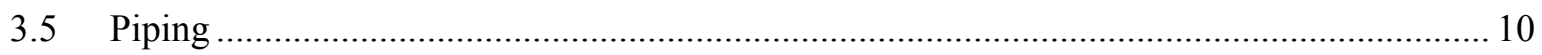

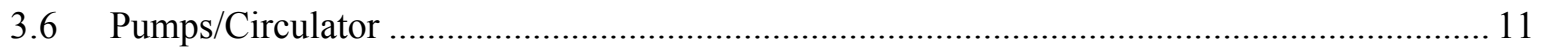

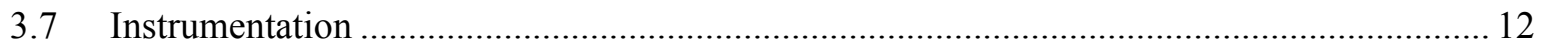

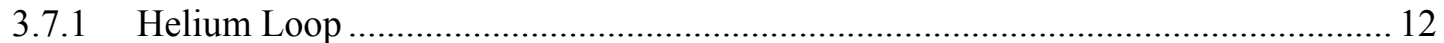

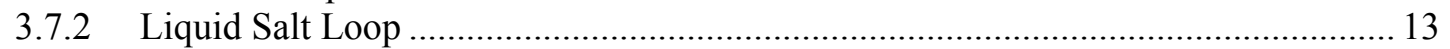

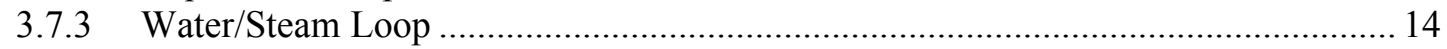

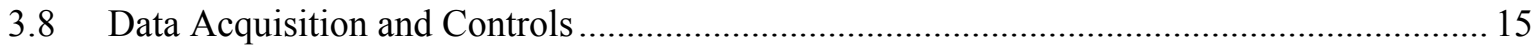

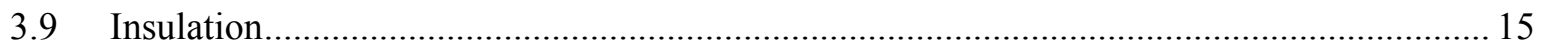

3.10 Aspen/HYSYS Model of the ARTIST Facility .............................................................. 15

3.11 Preliminary 3-D CAD Model of the ARTIST facility ......................................................... 18

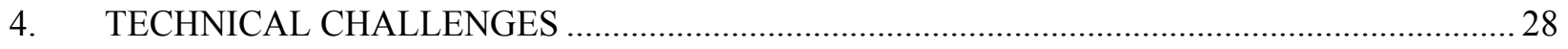

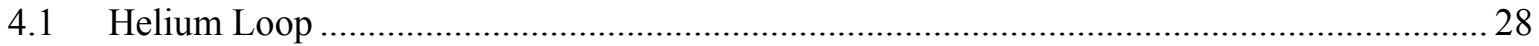

4.2 Intermediate Heat Transfer Loop .............................................................................. 28

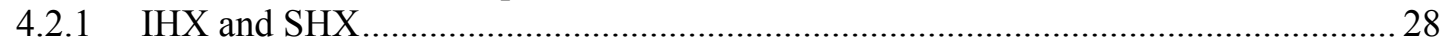

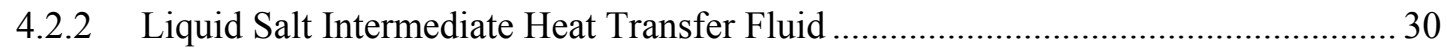

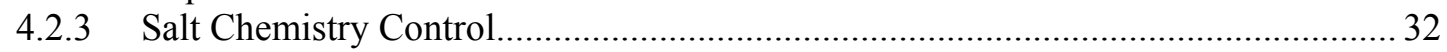

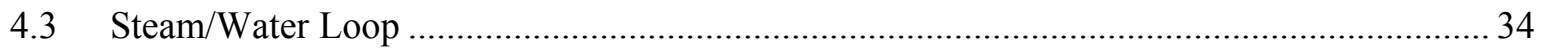

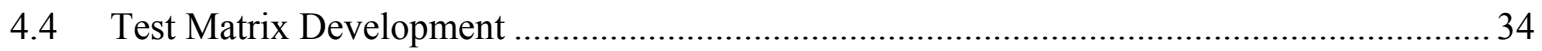

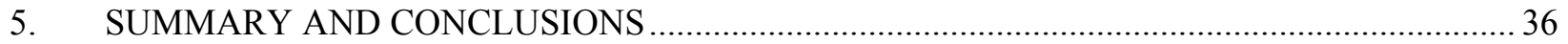




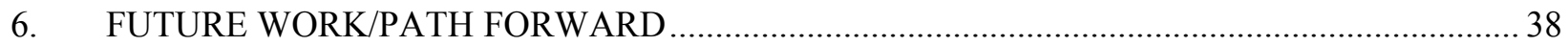

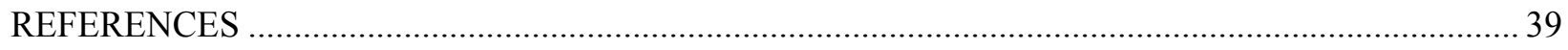

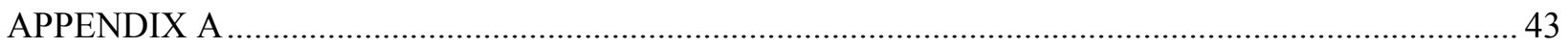

FIGURES

Figure 1. NGNP power and hydrogen production plant with three IHXs............................................ 2

Figure 2. Schematic of multi-fluid, multi-loop ARTIST thermal hydraulic test facility...........................5

Figure 3. Alloy $800 \mathrm{H}$ NPS 2 SCH 160 maximum operational pipe pressure rating versus

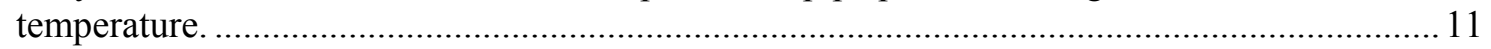

Figure 4. Aspen/HYSYS process flow diagram for system analysis of the ARTIST facility. .................. 16

Figure 5. Overview 3-D CAD model of the ARTIST facility............................................................. 20

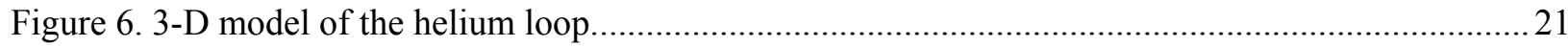

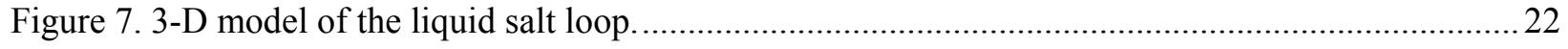

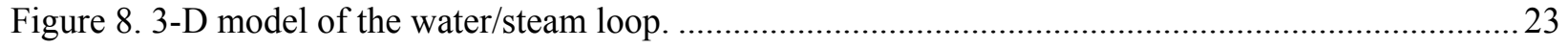

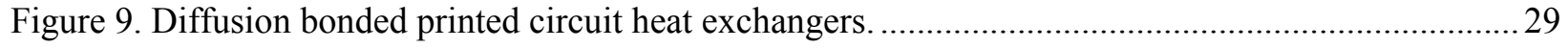

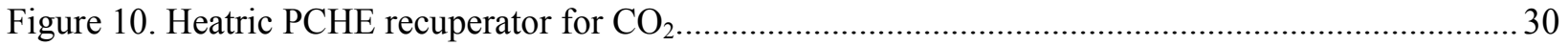

TABLES

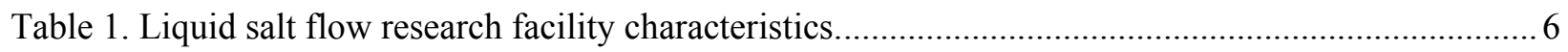

Table 2. Nominal conditions and flow rates based on $\mathrm{KF}-\mathrm{ZrF}_{4}$ flow of $1 \mathrm{~kg} / \mathrm{s}$, with $50^{\circ} \mathrm{C} \mathrm{IHX}$

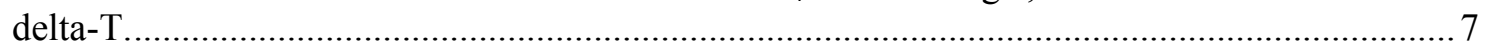

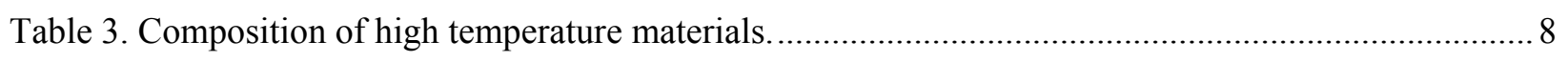

Table 4. Loop design operating conditions based on Aspen/HYSYS model........................................... 17

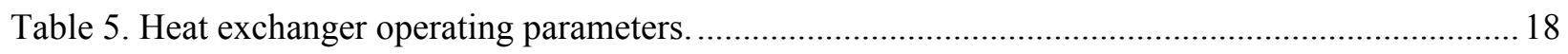

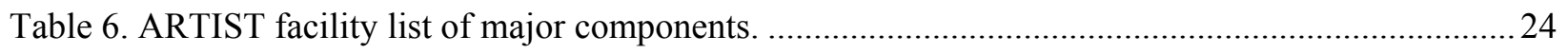

Table 7. Summary of figures of merit for candidate coolant fluids...................................................... 31

Table 8. Comparisons of FOM values for various coolant salt candidates............................................. 32 


\section{ACRONYMS}

AHTR Advanced High Temperature Reactor

ANSI American National Standards Institute

ARTIST Advanced Reactor Technology Integral System Test Facility

ASME American Society of Mechanical Engineers

DOE Department of Energy

FHR Fluoride Salt-Cooled High-Temperature Reactor

FOM figure of merit

HTC heat transfer component

IHX intermediate heat exchanger

INL Idaho National Laboratory

LWR Light Water Reactor

MSRE Molten Salt Reactor Experiment

MSTL Molten Salt Test Loop

NIFS National Institute for Fusion Science (Japan)

ORNL Oak Ridge National laboratory

PCHE printed circuit heat exchanger

PCM phase change material

PWR pressurized water reactor

R\&D research and development

SHX secondary heat exchanger

SMR small modular reactor

TES thermal energy storage

TNT Tohoku-NIFS-Thermofluid

$\mathrm{V} \& \mathrm{~V} \quad$ verification and validation

VHTR very high-temperature reactor 


\section{NOMENCLATURE}

$D_{h} \quad$ hydraulic diameter, $\mathrm{cm}$

$C_{p} \quad$ specific heat, $\mathrm{J} / \mathrm{kg} \mathrm{K}$

$f \quad$ Fanning friction factor

$G \quad$ mass flux, $\mathrm{kg} / \mathrm{m}^{2} \mathrm{~s}$

$h \quad$ heat transfer coefficient, $\mathrm{W} / \mathrm{m}^{2} \mathrm{~K}$

$j_{H} \quad$ Colburn $\mathrm{j}$ factor

$k \quad$ thermal conductivity, $\mathrm{W} / \mathrm{m} \mathrm{K}$

$L \quad$ length in the flow direction, $m$

$\dot{m} \quad$ mass flow rate, $\mathrm{kg} / \mathrm{s}$

$\mathrm{Nu} \quad$ Nusselt number

$P \quad$ pressure, $\mathrm{MPa}$

$\triangle P \quad$ pressure drop, $\mathrm{kPa}$

$\operatorname{Pr} \quad$ Prandtl number

$R_{o} \quad$ reference fluid property product for figures of merit

Re Reynolds number

$S \quad$ sensitivity factor for figures of merit

$T \quad$ temperature, ${ }^{\circ} \mathrm{C}$

$\Delta T \quad$ temperature difference, ${ }^{\circ} \mathrm{C}$

$\rho \quad$ fluid density, $\mathrm{kg} / \mathrm{m}^{3}$

$\mu \quad$ absolute viscosity, $\mathrm{N} \mathrm{s} / \mathrm{m}^{2}$ 


\section{OBJECTIVE}

Idaho National Laboratory (INL) is developing a high-temperature, multi-fluid, multi-loop test facility to support heat transfer, flow, materials, and thermal energy storage research for nuclear and nuclear-hybrid applications. In its initial configuration, the facility will include a high-temperature helium loop, a liquid salt loop, and a hot water/steam loop. Additional fluid capabilities such as sodium and supercritical $\mathrm{CO}_{2}$ may be added in the future. The three loops will be thermally coupled through an intermediate heat exchanger (IHX) and a secondary heat exchanger (SHX). Research topics to be addressed with this facility include the characterization and performance evaluation of candidate compact heat exchangers such as printed circuit heat exchangers (PCHEs) at prototypical operating conditions, flow and heat transfer issues related to core thermal hydraulics in advanced helium-cooled and salt-cooled reactors, and evaluation of corrosion behavior of new cladding materials and accident-tolerant fuels for LWRs at prototypical conditions. Based on its relevance to advanced reactor systems, the new facility has been named the Advanced Reactor Technology Integral System Test (ARTIST) facility.

This project supports the design, fabrication, assembly, and operation of a high-temperature flow and heat transfer loop and thermal energy storage system, with a focus on high-temperature advanced reactor applications. This work will advance the state of the art and technology readiness level of hightemperature intermediate heat exchangers (IHXs) for nuclear applications while establishing INL as a center of excellence for development and certification of this technology. The thermal energy storage capability will support research and demonstration activities related to process heat delivery for a variety of hybrid energy systems and grid stabilization strategies. Experimental results obtained from this research will assist in developing reliable predictive models for thermal-hydraulic design and safety codes over the range of expected advanced reactor operating conditions. Proposed/existing IHX heat transfer and friction correlations and criteria will be assessed with information on materials compatibility and instrumentation needs. The experimental database will guide development of appropriate predictive methods and will be available for code V\&V related to these systems.

\section{MOTIVATION}

Advanced High Temperature Reactor (AHTR) systems require research and development (R\&D), testing and qualification for critical systems, structures, and components. To meet the R\&D requirements, testing, and component qualification of AHTRs, a highly versatile test facility is needed. Effective and robust high-temperature heat transfer systems are fundamental to successful deployment of AHTRs for both power generation and nonelectric applications. Key activities of the test facility include

(1) qualification and testing of critical components in a high-temperature, high-pressure environment,

(2) materials development and qualification, and (3) manufacturer and supplier evaluation and development. A small-scale test loop could provide for early testing of components and design options that require special development tests before finalizing the design of AHTR components and qualifying them for operation in the larger loop or demonstration facility. The small loop will cost less to construct and operate. Since a suitable facility does not exist for testing advanced reactor heat transfer system components (e.g., intermediate heat exchanger (IHX), valves, etc.), reactor internals, or the interface with the heat application plant, a laboratory-directed research and development project was approved to initiate development of such a facility. 


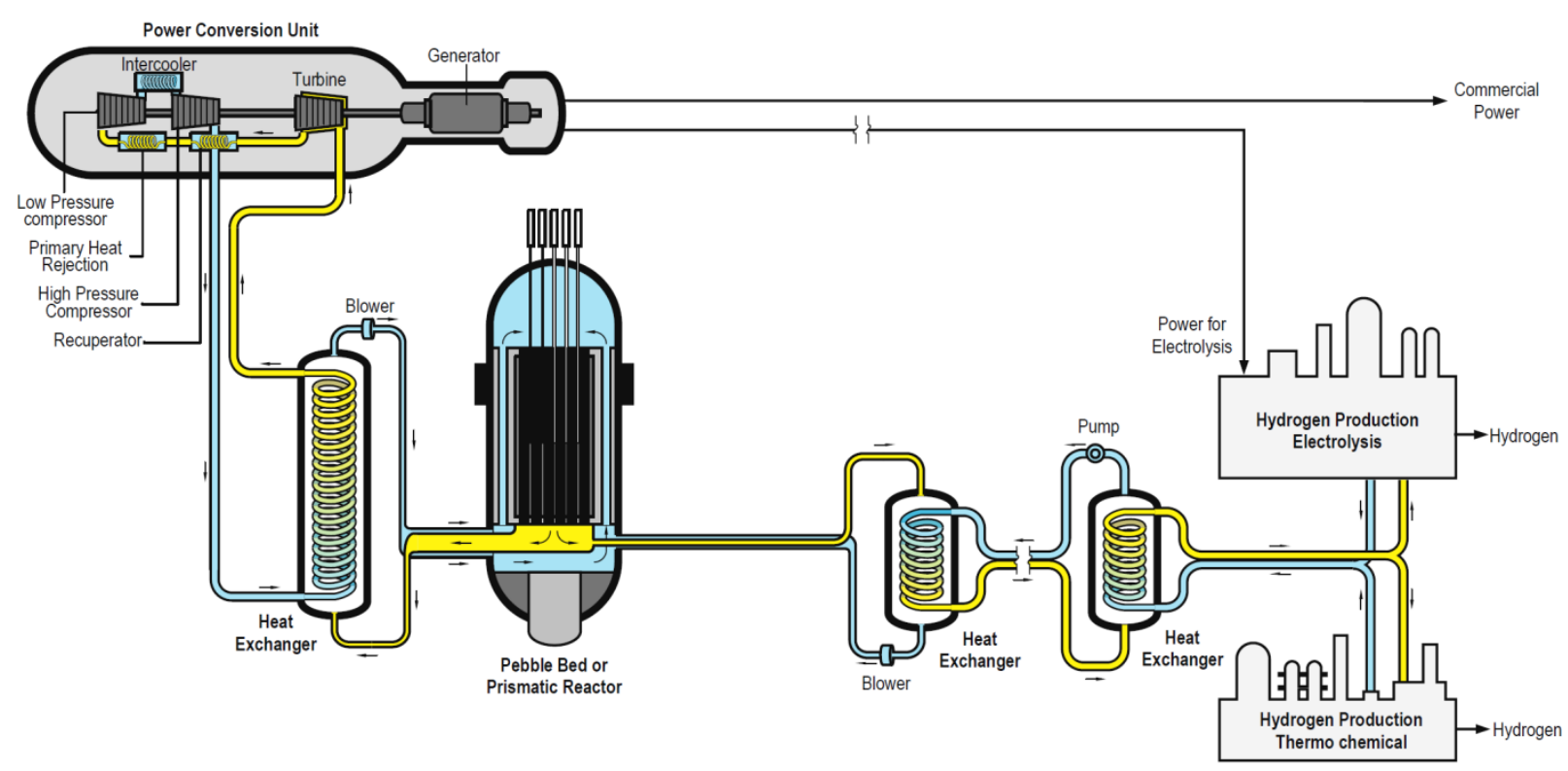

Figure 1. NGNP power and hydrogen production plant with three IHXs.

Plant designs often include an intermediate heat transfer loop (IHTL) with heat exchangers at either end to deliver thermal energy to the application while providing isolation of the primary reactor system. A conceptual layout for the Next Generation Nuclear Plant (NGNP) is shown in Figure 1. This concept indicates the use of a single IHX isolating the secondary power conversion unit working fluid from the primary He reactor coolant. For safety reasons and further isolation of the primary coolant from the process heat application (e.g., hydrogen production), a secondary heat exchanger is included in the process heat loop. In this case, a full intermediate heat transport loop is required, with an appropriate heat transport fluid.

Liquid salts have been identified as excellent candidate heat transport fluids for intermediate loops, supporting several types of advanced high temperature reactors [1, 2, 3, 4]. Liquid salts have also been proposed for use as a primary coolant for the Advanced High Temperature Reactor (AHTR) [5] and the Fluoride Salt-cooled High-Temperature Reactor (FHR) [6, 7]. Fluoride salt-coolants are eutectic binary or tertiary mixtures of fluoride salts with melting points in the range of 320 to $500^{\circ} \mathrm{C}$. FHRs have reactor outlet temperatures of $600^{\circ} \mathrm{C}$ or higher for high-efficiency power generation or process heat applications. Liquid salts exhibit superior heat transfer characteristics compared to He-cooled reactors. FHRs can also take advantage of effective passive natural circulation for decay heat removal.

PCHEs are strong candidate heat exchangers for intermediate heat transport loops due to their very high power density, requiring much less material per unit of heat duty compared to conventional shell and tube heat exchangers. PCHEs are fabricated from individual flat plates into which small flow channels are etched. The plates are stacked into alternating hot/cold layers and are typically diffusion-bonded, yielding a monolithic heat exchanger with strength equal to that of the base material. With appropriate materials, these heat exchangers can operate at high temperature and high pressure. PCHEs can, however, be susceptible to large thermal stresses during transient thermal hydraulic events [8].

In addition to the heat exchangers, each flow loop will include high-temperature test sections operating at prototypical conditions that can be customized to address specific research issues associated with each working fluid. Possible research topics for the high-temperature helium test section include flow distribution, bypass flow, heat transfer in prototypical prismatic core configurations under forced and natural circulation conditions $[9,10]$, parallel flow laminar instability during pressurized 
cooldown $[11,12]$, and turbulent heat transfer deterioration $[13,14]$. Oxidation effects associated with water or air ingress could also be examined [15].

The high-temperature test section in the liquid salt loop can be used for examination of materials issues, thermal stresses, and heat transfer. Metallic materials have been studied extensively in liquid salt environments $[1,2,3]$, but additional research is needed to evaluate the performance of ceramic and composite materials such as $\mathrm{SiC} / \mathrm{SiC}$ in liquid salt environments [7]. Fundamental heat transfer issues for liquid salts are related to the fact that these are high-Prandtl-number fluids with high viscosities and specific heats, and relatively low thermal conductivities. Accordingly, prototypical Reynolds numbers are small, in the laminar or transitional flow regimes and heat transfer enhancement strategies (e.g., extended surfaces) may have to be employed in the core and other components. Flow geometries of interest include prototypical prismatic core configurations and pebble beds, as well as heat exchanger flow passages. The high Prandtl number reduces the potential for thermal shock (compared to low-Prandtl-number liquid metal coolants), but the possibility of large thermal stresses still exists [7]. Bypass flow can also be an issue for prismatic reactor core configurations with liquid salt coolants.

The liquid salt loop will include a thermal energy storage (TES) system for support of thermal integration studies. The TES system will be based on freezing and melting of the salt acting as a hightemperature phase change material (PCM). A number of salts have been proposed as high-temperature PCMs for solar energy applications [16, 17]. The advantage of using a PCM is that thermal energy can be supplied to the process at a nearly constant temperature, taking advantage of the latent heat of melting.

The high-temperature test section in the steam/water loop will be used primarily for prototypic evaluation of new cladding materials and accident-tolerant fuels. It will be designed to characterize the thermal, chemical, and structural properties of candidate advanced fuel cladding materials and designs under various simulated flow and internal heating conditions to mimic operational reactor conditions prior to in-reactor testing. The capability for out-of-pile mock-up testing of candidate (surrogate) fuel-clad systems is essential for reactor readiness, in particular when innovative fuel cladding will be in direct contact with the test reactor primary coolant system without secondary containment. Careful control of water chemistry will be essential for these studies; a water chemistry control section is included in the design of the loop.

Flow-induced vibration of fuel rod bundles has been identified as an important issue for sodium-cooled reactors [18]. The high-temperature test section of the hot water loop can also potentially be used to study flow-induced vibration of simulated sodium-cooled reactor fuel rod bundles. Hot water at $200^{\circ} \mathrm{C}$ and $1.38 \mathrm{MPa}$ matches the density of sodium. This condition is well within the operational range of the proposed loop.

Research conducted in these flow loops will also support V\&V efforts. Experimental data for validation is required to gain confidence in the existing theoretical and empirical correlations. Development of such an experimental database is needed to advance the technology readiness level of various reactor concepts and high-temperature components. The database will also be used to evaluate the performance of existing models and correlations in predicting thermal hydraulic phenomena. New models and/or correlations will be developed as needed. 


\section{PRELIMINARY DESIGN OF THE MULTI-PURPOSE THERMAL HYDRAULIC LOOP}

\subsection{Facility Description}

\subsubsection{Process Flow Diagram}

A process flow diagram for the multi-fluid, multi-loop test facility is shown in Figure 2. The facility includes three thermally interacting flow loops: helium, liquid salt, and steam/water. The helium loop will be initially charged from pressurized gas storage cylinders to the loop operating pressure of $7 \mathrm{MPa}$. The loop can be evacuated prior to charging for removal of air. This process can be repeated with intermediate gas venting via the deaeration vent to achieve the desired loop He purity level. Helium flow through the loop will be driven by a water-cooled centrifugal gas circulator rated for high-pressure service, with a design flow rate up to $525 \mathrm{LPM}$ at $7 \mathrm{MPa}(11,300 \mathrm{SLPM})$ and a loop pressure drop of $100 \mathrm{kPa}$. The circulator flow rate will be controlled by means of a variable-frequency drive coupled to the motor. The helium circulator will be designed to operate with a maximum helium temperature of $100^{\circ} \mathrm{C}$. It is therefore located in the low-temperature section of the helium flow loop. The gas is preheated to intermediate temperature by flowing through a helium-to-helium recuperator $(60 \mathrm{~kW}$ duty) that transfers heat from the intermediate-temperature helium return flow to the low-temperature stream. The hightemperature portion of the flow loop is designed to handle helium temperatures up to $800^{\circ} \mathrm{C}$. This temperature will be achieved using a high-temperature in-line electrical gas heater located downstream of the recuperator. The nominal power requirement for the high-temperature gas heater is $60 \mathrm{~kW}$.

The helium loop will include a high-temperature test section for heat transfer and materials studies. Downstream of the test section, the helium gas flows through a heat exchanger where heat will be transferred to the adjacent liquid salt loop using a scaled version of an IHX. The baseline design for this heat exchanger will be a high-efficiency compact microchannel PCHE with a nominal heat duty of $55 \mathrm{~kW}$. Analysis of a PCHE operating with He as the hot fluid and liquid salt as the cold fluid is provided in reference [8]. Downstream of the IHX, the helium flows through an intermediate-temperature test section and the recuperator to transfer heat back to the inlet stream. Downstream of the recuperator, the helium flows through a water-cooled chiller $(10 \mathrm{~kW})$ to cool it down to the gas circulator operating temperature. The baseline design for the He-He recuperator will also be a PCHE. In addition to its heat recuperation role, this heat exchanger simulates an IHX for the case in which $\mathrm{He}$ is used as an intermediate heat transfer fluid, albeit at lower operating temperatures. Performance data obtained from this recuperator will provide useful validation data for the reactor system application. The He-He version of the IHX operates with essentially balanced high pressure on both sides, minimizing the possibility of leakage of primary fluid to the secondary side.

The center part of Figure 2 shows the liquid salt portion of the multi-loop facility. The loop will be charged with salt from the salt storage tank. This tank will include a heater designed to heat the frozen salt to a temperature above its melting point. The head space in the salt storage tank will be maintained at slightly elevated pressure with an inert cover gas. The inert gas will prevent in-leakage of air or moisture, minimizing the potential for salt contamination. During startup, liquid salt will drain to the pump inlet by gravity, with assist from the cover gas pressure, as needed. The salt pump will be designed to operate at $450^{\circ} \mathrm{C}$ at low pressure $(\sim 0.2 \mathrm{MPa})$. It will provide salt flow rates up to $20 \mathrm{LPM}$. A standard stainless steel such as SS316 may be suitable for the pump material, but other alloys will also be considered. The entire liquid salt flow loop will be heat-traced to prevent salt from freezing and causing a flow blockage. Downstream of the pump, the salt flow rate will be measured using a high-temperature ultrasonic flow transducer. The salt temperature will be boosted as needed to the desired intermediate temperature using an in-line electrical auxiliary heater. Careful control of salt chemistry will be critical for successful operation of this loop; a salt chemistry control section will be installed at the intermediate temperature 


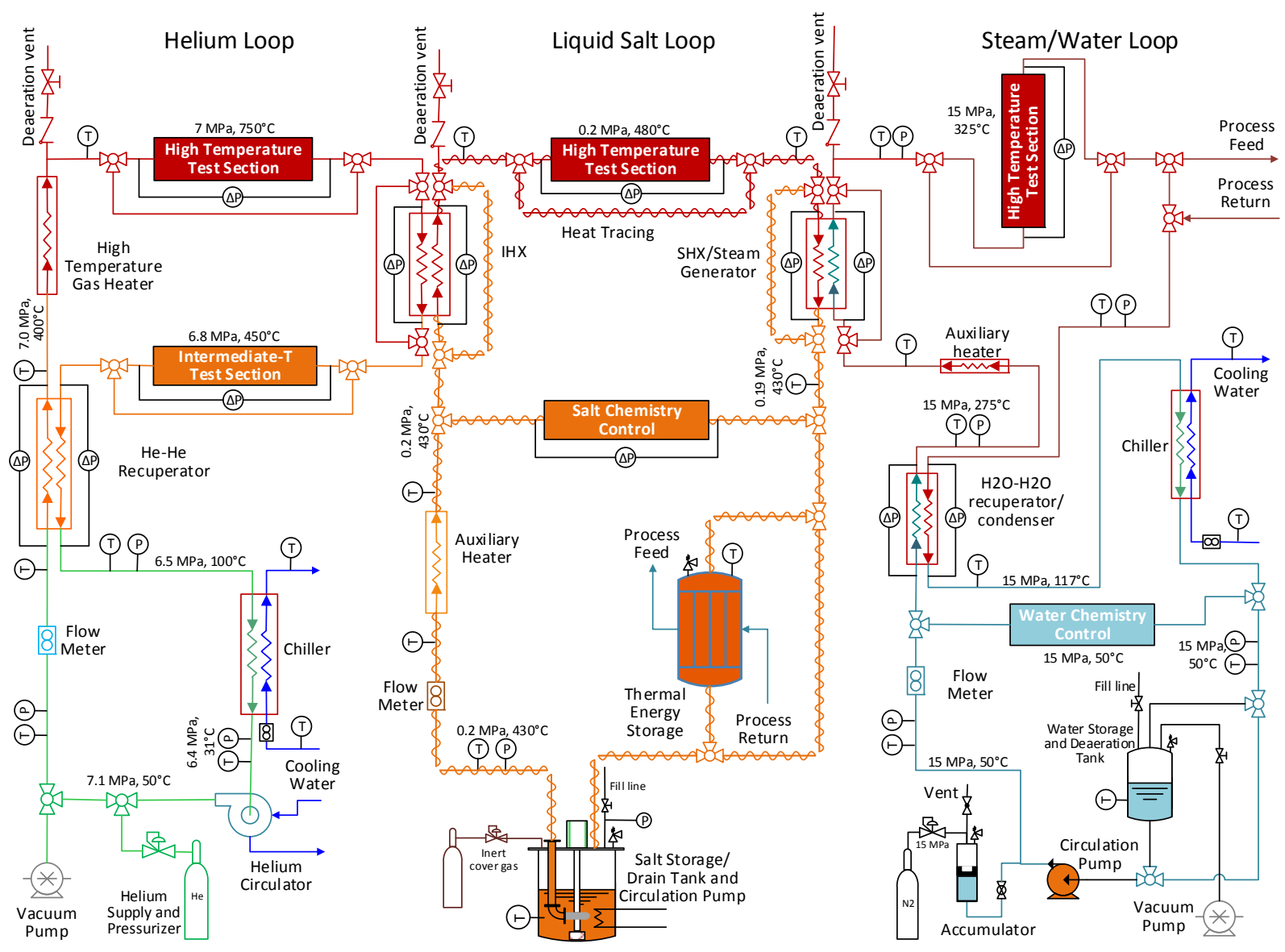

Figure 2. Schematic of multi-fluid, multi-loop ARTIST thermal hydraulic test facility.

location. The salt temperature will increase to $\sim 480^{\circ} \mathrm{C}$ as it flows through the IHX and heat is transferred from the helium loop to the salt loop. Note that the He-salt IHX will have high-pressure helium on one side and low-pressure salt on the other, establishing the potential for high-temperature creep and leakage of primary He into the salt loop, emphasizing the need for demonstrating complete IHX integrity at prototypical conditions.

For independent operation of the liquid salt loop, the IHX will not be required. An IHX bypass will enable salt flow directly to the high-temperature test section without the pressure drop associated with the IHX. The auxiliary heater will be designed to independently heat the salt to the maximum operating temperature of $480^{\circ} \mathrm{C}$ even when the IHX is bypassed. Its nominal design heater power will be $75 \mathrm{~kW}$. Downstream of the high-temperature test section, the liquid salt flows through the SHX, transferring heat to the tertiary steam/water loop. A bypass line around the SHX is also provided for cases in which the salt loop will be operated independently of the steam/water loop. The salt can then flow directly back to the pump or it can flow through a thermal energy storage (TES) system for process integration studies.

The right-hand side of Figure 2 shows the steam/water tertiary loop. The SHX can serve as a steam generator or simply a single-phase heat exchanger, depending on conditions to be simulated in the tertiary loop. For most tests, conditions in the tertiary loop will be intended to simulate conditions in the primary loop of a pressurized water reactor (PWR). PWR conditions will be needed for materials/ corrosion studies of accident-tolerant fuels, new cladding materials, CRUD formation, etc. Alternately, at lower operating pressure the tertiary loop can simulate the secondary side of a PWR system, with steam generation for process integration studies. Flow through the hot water loop will be produced by a pump designed to operate at $15 \mathrm{MPa}$ with a nominal water flow rate of $5.7 \mathrm{LPM}$ at $15 \mathrm{MPa}$ and $40^{\circ} \mathrm{C}$. 
Downstream of the pump, the water flows through a recuperator designed to recover heat from the high-temperature portion of the loop. The baseline recuperator inlet and outlet water temperatures will be $50^{\circ} \mathrm{C}$ and $275^{\circ} \mathrm{C}$, respectively. The water is heated further to $325^{\circ} \mathrm{C}$ by heat transfer in the SHX. For cases in which the SHX is not present or is bypassed, an auxiliary heater will be used to achieve the desired $325^{\circ} \mathrm{C}$ test section inlet temperature. Note that the SHX will also operate with a large pressure differential between the water side (15 MPa) and the salt side (0.2 MPA), establishing the potential for water leakage into the salt, and emphasizing the need to demonstrate full SHX integrity at these conditions. Hightemperature creep should not be a concern at these temperatures, however. At $15 \mathrm{MPa}$, the maximum water temperature $\left(325^{\circ} \mathrm{C}\right)$ is well below the saturation temperature, so the water remains in the liquid phase throughout the system for the baseline case. The high-temperature test section in the water loop will have a vertical orientation to support boiling (at pressures lower than $15 \mathrm{MPa}$ ) and/or natural circulation studies. Simulated PWR core geometries in the test section will support research on new cladding materials, accident-tolerant fuels, etc. Hot water or steam can be supplied to other co-located processes or experiments via the process feed and process return lines. After flowing through the return side of the recuperator, the water temperature is decreased to $117^{\circ} \mathrm{C}$. It is further reduced to the pump operating temperature of $50^{\circ} \mathrm{C}$ by means of a water-cooled chiller. Pressure in the hot water loop will be maintained by means of a piston accumulator with regulated nitrogen on the gas side. The water storage and deaeration tank will be plumbed to a vacuum pump to allow for air removal. The water can also be directed to flow through a chemistry control section. This part of the loop will be designed to establish the loop water chemistry. Most often, PWR water chemistry will be established. The chemistry control section will include filtering, a water softener, and a reverse osmosis conditioner for deionization/demineralization. It will also provide the ability to establish the correct $\mathrm{pH}$ value to ensure prototypical PWR conditions.

\subsubsection{Facility Scale and Operating Conditions}

Selection of the overall scale of this facility in terms of flow rates, pump requirements, heater power, heat exchanger duty, piping size, etc. is based on a compromise between capability and cost. A survey of existing liquid salt flow research facilities was performed to provide guidance on sizing of the INL salt loop. Results of the survey are presented in Table 1 . As expected, the university facilities are relatively small, with salt flow rates much less than $1.0 \mathrm{~kg} / \mathrm{s}$. The ORNL facility and the Tohoku-NIFS Thermofluid (TNT) loop in Japan have flow rates on the order of $1.0 \mathrm{~kg} / \mathrm{s}$. By far the largest facility listed is the Molten Salt Test Loop (MSTL) at Sandia National Laboratory, with a salt flow rate of up to $50 \mathrm{~kg} / \mathrm{s}$. Based on the expected funding available for the INL facility and the desire to develop a facility of relevant scale for heat exchanger characterization and other research objectives, the INL facility has been designed to support a liquid salt flow rate of $1 \mathrm{~kg} / \mathrm{s}$ with a temperature rise across the IHX of $50^{\circ} \mathrm{C}$.

Table 1. Liquid salt flow research facility characteristics.

\begin{tabular}{|c|c|c|c|c|c|}
\hline $\begin{array}{l}\text { Institution and } \\
\text { Reference }\end{array}$ & Salt & $\begin{array}{c}\text { Operating } \mathrm{T} \\
\left({ }^{\circ} \mathrm{C}\right)\end{array}$ & $\begin{array}{c}\text { Maximum } \mathrm{P} \\
(\mathrm{kPa})\end{array}$ & $\begin{array}{c}\text { Flow Rate } \\
(\mathrm{kg} / \mathrm{s})\end{array}$ & Application \\
\hline ORNL [19] & FLiNaK & 700 & atmospheric & 4.5 & $\begin{array}{c}\text { Nuclear/ } \\
\text { PB-AHTR }\end{array}$ \\
\hline Sandia MSTL [20] & $60 \mathrm{NaNO}_{3}-40 \mathrm{KNO}_{3}$ & $300-585$ & 580 & $44-50$ & solar \\
\hline Korea [21] & FliNaK & & & .003 & nuclear \\
\hline U Wisconsin [22] & FLiNaK, KCl-MgCl & 600 & & $8.3 \times 10^{-4}$ & nuclear \\
\hline U Wisconsin [22] & $\mathrm{KNO}_{3}-\mathrm{NaNO}_{3}, 60: 40$ & $\sim 200$ & 200 & & nuclear \\
\hline $\begin{array}{l}\text { NIFS-Japan, TNT } \\
\text { Loop [23] }\end{array}$ & $\begin{array}{l}\mathrm{KNO}_{3}-\mathrm{NaNO}_{2}-\mathrm{NaNO}_{3} \\
\text { 53:40:7 (HT salt) }\end{array}$ & $\sim 200$ & & 0.645 & Fusion \\
\hline Ohio State U [24] & $\mathrm{FLiNaK}, \mathrm{KF}-\mathrm{ZrF}_{4}$ & $600-700$ & atmospheric & 0.12 & nuclear \\
\hline INL ARTIST & $\mathrm{KF}-\mathrm{ZrF}_{4}$ & $400-500$ & 200 & 1.0 & nuclear \\
\hline
\end{tabular}


Once this specification is adopted, and a salt has been selected, the IHX heat duty is fixed. Required flow rates of the remaining fluids in the multi-fluid loop can subsequently be calculated based on appropriate values of temperature change across the IHX and/or the SHX. Salt flow characteristics for the planned INL ARTIST facility are listed at the bottom of the table.

Approximate operating conditions, heat exchanger duties and flow rates for the ARTIST facility are listed in Table 2. The table provides the operating conditions and flow rates for $\mathrm{KF}-\mathrm{ZrF}, \mathrm{He}, \mathrm{H}_{2} \mathrm{O}$ liquid, supercritical $\mathrm{CO}_{2}$, and $\mathrm{Na}$, corresponding to a $\mathrm{KF}-\mathrm{ZrF}_{4}$ flow rate of $1 \mathrm{~kg} / \mathrm{s}$ and a delta-T across the IHX (salt side) of $50^{\circ} \mathrm{C}$, which yields a heat exchanger duty of $52.6 \mathrm{~kW}$. Each fluid is listed with an appropriate application-oriented heat exchanger delta-T. For example, the expected temperature difference for primary helium across the IHX is $\sim 300^{\circ} \mathrm{C}$ in the very high-temperature reactor (VHTR) application. Supercritical $\mathrm{CO}_{2}$ and sodium are included in the table due to their importance for nuclear applications. These fluids will not be employed in the initial configuration of the multi-fluid loop, however. Mass and actual volume flow rates are listed for all the fluids. Volumetric flow rates for gases are also listed in terms of standard liters per minute (SLPM). Volume flow rates for liquids are also listed in terms of gallons per minute (gpm).

The loop will be designed such that tests can be run in an automatic or "unattended" condition for long periods with minimal operator supervision, while automatically recording relevant data from system sensors. Operator pre-set alarms and safety interlocks will be used to shut down the power source for heater and pump/circulator should an off-normal event occur (e.g., sudden loss of pressure in the pressurized loop/leakage, increase in temperature beyond the set limit). Set points will be established for temperature, pressure, and flow rate.

Table 2. Nominal conditions and flow rates based on $\mathrm{KF}^{-} \mathrm{ZrF}_{4}$ flow of $1 \mathrm{~kg} / \mathrm{s}$, with $50^{\circ} \mathrm{C} \mathrm{IHX}$ delta-T.

\begin{tabular}{|c|c|c|c|c|c|c|c|c|}
\hline Fluid & $\begin{array}{c}\mathrm{P} \\
\mathrm{MPa}\end{array}$ & $\begin{array}{c}\mathrm{T}_{\text {mean }} \\
{ }^{\circ} \mathrm{C}\end{array}$ & $\begin{array}{c}\mathrm{HX} \Delta \mathrm{T} \\
{ }^{\circ} \mathrm{C}\end{array}$ & $\begin{array}{c}\mathrm{HX} \text { Duty } \\
\mathrm{kW}\end{array}$ & $\begin{array}{c}\text { Mass } \\
\text { flow rate } \\
\mathrm{kg} / \mathrm{s}\end{array}$ & $\begin{array}{c}\text { Volume } \\
\text { flow rate } \\
\text { L/min } \\
\text { (actual) }\end{array}$ & $\begin{array}{c}\text { Volume } \\
\text { flow rate } \\
\text { SLPM }\end{array}$ & $\begin{array}{c}\text { Volume } \\
\text { flow rate } \\
\text { gpm }\end{array}$ \\
\hline $\mathrm{KF}-\mathrm{ZrF}_{4}$ & 0.2 & $\sim 450$ & 50 & 52.6 & 1 & 19.9 & $\mathrm{n} / \mathrm{a}$ & 5.25 \\
\hline $\mathrm{He}$ & 7 & 600 & 300 & 52.6 & .0337 & 524 & 11330 & $\mathrm{n} / \mathrm{a}$ \\
\hline $\mathrm{H}_{2} \mathrm{O}$ liq & 15 & 300 & 50 & 52.6 & .19 & 16.5 & $\mathrm{n} / \mathrm{a}$ & 4.37 \\
\hline $\mathrm{SCO}_{2}$ & 20.5 & 372 & 150 & 52.6 & .25 & 89.0 & 7648 & $\mathrm{n} / \mathrm{a}$ \\
\hline $\mathrm{Na}$ & 0.2 & 600 & 50 & 52.6 & 0.828 & 64.4 & $\mathrm{n} / \mathrm{a}$ & 17.0 \\
\hline
\end{tabular}


Table 3. Composition of high temperature materials.

\begin{tabular}{|c|c|c|c|c|c|c|c|}
\hline Components & \multicolumn{7}{|c|}{ Quantity in Alloy, weight \% } \\
\hline & 617 & 600 & $800 \mathrm{H}$ & 230 & Alloy N & Alloy 242 & SS 316 \\
\hline Nickel & $44.5 \mathrm{~min}$ & $72.0 \mathrm{~min}$ & $30.0-35.0$ & $\begin{array}{l}57 \text { as } \\
\text { balance }\end{array}$ & 71 & 65 & $10.0-14.0$ \\
\hline Chromium & $20.0-24.0$ & $14.0-17.0$ & $19.0-23.0$ & 22 & 7 & $7.0-9.0$ & $16.0-18.0$ \\
\hline Iron & $3.0 \max$ & $6.0-10.0$ & $39.5 \mathrm{~min}$ & $3 \max$ & $5 \max$ & $2.0 \max$ & as balance \\
\hline Molybdenum & $8.0-10.0$ & & & 2 & 16 & $24.0-26.0$ & $2.0-3.0$ \\
\hline Manganese & $1.0 \max$ & $1.0 \max$ & & 0.5 & $0.80 \max$ & $0.8 \max$ & $2.0 \max$ \\
\hline Carbon & $0.05-0.15$ & $0.15 \max$ & $0.05-0.10$ & 0.1 & $0.08 \max$ & $0.03 \max$ & $0.08 \max$ \\
\hline Silicon & $1.0 \max$ & $0.5 \max$ & & 0.4 & $1 \max$ & $0.8 \max$ & $0.75 \max$ \\
\hline Sulfur & $0.015 \max$ & & & & & & $0.03 \max$ \\
\hline Copper & $0.5 \max$ & $0.5 \max$ & & & $0.35 \max$ & $0.2 \max$ & \\
\hline Cobalt & $10.0-15.0$ & & & $5 \max$ & $0.20 \max$ & $2.5 \max$ & \\
\hline Aluminum & $0.8-1.5$ & & $0.15-0.60$ & 0.3 & $\mathrm{Al}+\mathrm{Ti}=$ & $0.5 \max$ & \\
\hline Titanium & $0.6 \max$ & & $0.15-0.60$ & & $0.35 \max$ & $0.006 \max$ & \\
\hline Boron & $0.006 \max$ & & & $0.015 \max$ & & & \\
\hline Tungsten & & & & 14 & $0.50 \max$ & & \\
\hline Others & & & & $\mathrm{La}=0.02$ & & & $\begin{array}{l}\mathrm{P}=0.045 \\
\max \mathrm{N}= \\
0.10 \mathrm{max}\end{array}$ \\
\hline
\end{tabular}

\subsubsection{Thermal Energy Storage System}

A phase-change thermal energy storage system (TES) will be included in the liquid salt loop for support of hybrid energy thermal integration studies. The PCM will be $\mathrm{KF}_{-} \mathrm{ZrF}_{4}$. Final sizing of this system will depend on the requirements of integrated systems. An initial size assumption is that the system will be in the form of a cylindrical tank with a diameter of $0.75 \mathrm{~m}$ and a height of $1.5 \mathrm{~m}$. For this case, the volume of PCM will be $663 \mathrm{~L}$ and the thermal capacity will be $978 \mathrm{MJ}(272 \mathrm{~kW} \cdot \mathrm{hr})$ at a constant temperature of $390^{\circ} \mathrm{C}$. These estimates were made using the latent heat of fusion for $\mathrm{KF}$ (486 J/gm). At this time, the latent heat of fusion for $\mathrm{KF}-\mathrm{ZrF}_{4}$ is not available in the literature. The TES will be designed essentially as a stand-alone system, but the salt can be withdrawn from the storage tank into the salt loop for chemistry control. The TES will also serve as an auxiliary salt storage tank.

\subsection{Construction Materials}

Candidate materials of construction include materials that exhibit (in varying degrees) hightemperature tensile strength, creep resistance and compatibility with liquid salts. The current discussion is limited to metallic materials. Longer-term $R \& D$ programs will evaluate ceramic and composite designs. Issues that must be addressed during the design process include materials compatibility with both fluoride and chloride salts. Some of the materials options that could potentially be used for construction of the various portions of the test facility are listed in Table 3. Structural materials under consideration include high temperature Ni alloys that exhibit good strength and corrosion resistance at high temperatures. Out of all the alloys listed, Alloy $800 \mathrm{H}$ is the only one that has been approved/codified up to $760^{\circ} \mathrm{C}$ per American Society of Mechanical Engineers (ASME) code case requirements. 
Hastelloy $\mathrm{N}$ would be the preferred choice for construction of the molten salt portion of the loop. Hastelloy $\mathrm{N}(\mathrm{HN})$ is the only material for which extensive corrosion test data are available with fluoride salts, mainly due to experience with the molten salt breeder reactor program at ORNL, which proved the feasibility of the salt as a coolant in the reactor system and showed negligible corrosion at high temperature under long-term exposure. The alloys that exhibit the greatest corrosion resistance to liquid salts are not codified for use in nuclear applications. Those that are currently codified are inferior, and their use would result in shorter heat exchanger life. Furthermore, the commercial availability of Hastelloy $\mathrm{N}$ is extremely limited or nonexistent, so alternatives such as $800 \mathrm{H}$ will have to be considered. Stainless steel 316 will be the material of choice for the water loop.

\subsection{Heaters}

\subsubsection{Fluid Heaters}

There are four heaters in the multi-loop facility (see Figure 2). The primary heater will be a high-temperature gas heater on the helium loop. This heater will have a nominal power rating of $60 \mathrm{~kW}$ and a gas outlet temperature up to $750^{\circ} \mathrm{C}$. Commercially available options for this heater include circulation heaters which consist of high-temperature heating elements mounted on a pressure vessel with integral screw plug or American National Standards Institute (ANSI) flanged inlet and outlet flow connections. These are available in alloy 800 or $800 \mathrm{H}$ for high-temperature applications, rated up to $870^{\circ} \mathrm{C}$. Standard units are available to ANSI pressure class 600 rating. Class 600 fittings are rated for pressures up to $10 \mathrm{MPa}$ (1500 psig) at room temperature, they are significantly de-rated at higher temperatures. For the high-temperature He loop, this pressure rating will not be sufficient. A custom design will be required. One possibility is to use an internally insulated vessel to house the heating elements and the flowing gas. This strategy was recommended for several components in the conceptual design report [25] of a large-scale (2 MW) high-temperature gas loop facility for INL. Using this strategy, each component is internally insulated and shielded by a cooling liner to isolate the pressure vessel from the high internal temperatures. High-performance silica micropore insulation can be used to line the interior of the vessels.

Another possible strategy for the high-temperature gas heater is to use a radiant heater surrounding the tubing in which the gas is flowing. This strategy was used in the Ohio State University hightemperature helium facility [26]. The tubing can be coiled inside the radiant heater to achieve the necessary heat transfer length. The flow can also be subdivided among several tubes. This strategy is relatively inefficient since the gas is not in direct contact with the heating element, as with a circulation heater. Also, the tubing temperature will actually be higher than the gas temperature, reducing its strength and pressure rating.

The liquid salt loop includes an auxiliary heater. It will be designed to independently heat the salt to the maximum operating temperature of $480^{\circ} \mathrm{C}$ when the IHX is bypassed. Its nominal design heater power will be $75 \mathrm{~kW}$. Since the salt loop operates at low pressure and lower temperature (compared to the He heater) a commercially available circulation heater with suitable materials (e.g., alloy $800 \mathrm{H}$ ) should be sufficient for this application. For the salt storage tank, a commercially available immersion heater can be suspended in the salt. Based on an estimate of the maximum required volume of salt in the storage tank and estimates of the solid salt specific heat and latent heat of fusion, the storage tank heater should be sized at $\sim 75 \mathrm{~kW}$ to heat the salt from room temperature to above the melting point within a reasonable time period ( 100 $\mathrm{min})$.

The steam/water loop also includes an auxiliary heater. It will be designed to heat the water from $275^{\circ} \mathrm{C}$ to $325^{\circ} \mathrm{C}$ when the SHX is bypassed. The corresponding power requirement is $52.5 \mathrm{~kW}$, so the heater should be sized for at least $60 \mathrm{~kW}$. The biggest challenge for the hot water loop is high pressure 
(15 MPa). A circulation heater enclosed within a stainless-steel 600-lb class flanged vessel should be sufficient for service up to $350^{\circ} \mathrm{C}$.

\subsubsection{Heat Tracing}

The melting point of $\mathrm{KF}-\mathrm{ZrF}_{4}$ is well above ambient temperature $\left(390^{\circ} \mathrm{C}\right)$; thus the entire liquid salt will be equipped with trace heaters in order to avoid localized freezing and possible flow blockage. For these temperatures, heat tracing will be accomplished using mineral-insulated heating cables. Chromalox MI cables [27] use a high-temperature nickel alloy sheath and are rated to $590^{\circ} \mathrm{C}$, which should be sufficient for this application. The liquid salt piping will have the heat tracing tightly coiled around its outer diameter, with high temperature insulation outside of the heat tracing to minimize heat loss.

\subsection{Valves}

As indicated in the facility schematic Figure 2, numerous valves will be used in the multi-loop system. Specifications (temperature, pressure, material) for each valve will be dependent on its location in the test facility. Valve specifications for the highest-temperature part of the helium flow loop $\left(750^{\circ} \mathrm{C}\right.$, $7 \mathrm{MPa}$ ) are very challenging, especially recognizing the leak characteristics of He gas. In fact, testing and characterization of valve performance at VHTR conditions with He gas was identified as one of several important research needs justifying the design and construction of a large-scale high-temperature gas test facility at INL for component and materials testing [28]. As noted in reference [28], it may be necessary to design the highest temperature sections to be reconfigurable without the use of valves. For example the high-temperature test section could simply be removed and replaced with a flanged pipe section rather than bypass the test section using 3-way valves.

Cast stainless steel valves that meet ASME Boiler and Pressure Vessel Code Section II up to Class 4500 , rated for service at $750^{\circ} \mathrm{C}$ up to $8.8 \mathrm{MPa}$ are commercially available [28]. Applicability of these items for the He loop will be assessed.

Since the liquid salt loop operates at low pressure, the primary challenge for valve specification will be the materials of construction, seals, seats, etc. Fluoride-salt-compatible materials will be required (see Section 3.2). In the steam/water loop the most demanding valve specification will be $15 \mathrm{MPa}$ pressure at $350^{\circ} \mathrm{C}$. Stainless steel valves, NPS1, class 1500 , are rated to 151.6 bar at $350^{\circ} \mathrm{C}$ [28].

\subsection{Piping}

Based on the design mass flow rate for the helium loop (see Table 2), and the pressure and temperature requirements, a pipe size of NPS2, schedule 160 will provide reasonable flow velocities. For NPS2 schedule 160 piping, with the design helium mass flow rate of $0.0337 \mathrm{~kg} / \mathrm{s}$, at $600^{\circ} \mathrm{C}$ and $7 \mathrm{MPa}$, the flow velocity is $6.0 \mathrm{~m} / \mathrm{s}$. This velocity is low enough to avoid large frictional losses. However, even using schedule 160 piping, the pressure rating in the highest temperature part of the loop is unacceptable with standard SS316 piping. The pressure rating for NPS2, schedule 160 piping was evaluated for alloy $800 \mathrm{H}$ as a function of temperature based on its maximum allowable stress. The result is presented in Figure 3. At $750^{\circ} \mathrm{C}$, the pressure rating is $\sim 6.9 \mathrm{MPa}$, which is just below the desired 7.0 MPa rating. It may therefore be necessary to use internally insulated piping for the highest temperature portions of the helium loop, as noted in Section 3.3 in the discussion about heaters. Another possibility is to use extra-heavy schedule pipe. However, commercial availability of nonstandard pipe with special alloys such as $800 \mathrm{H}$ will be very limited. 


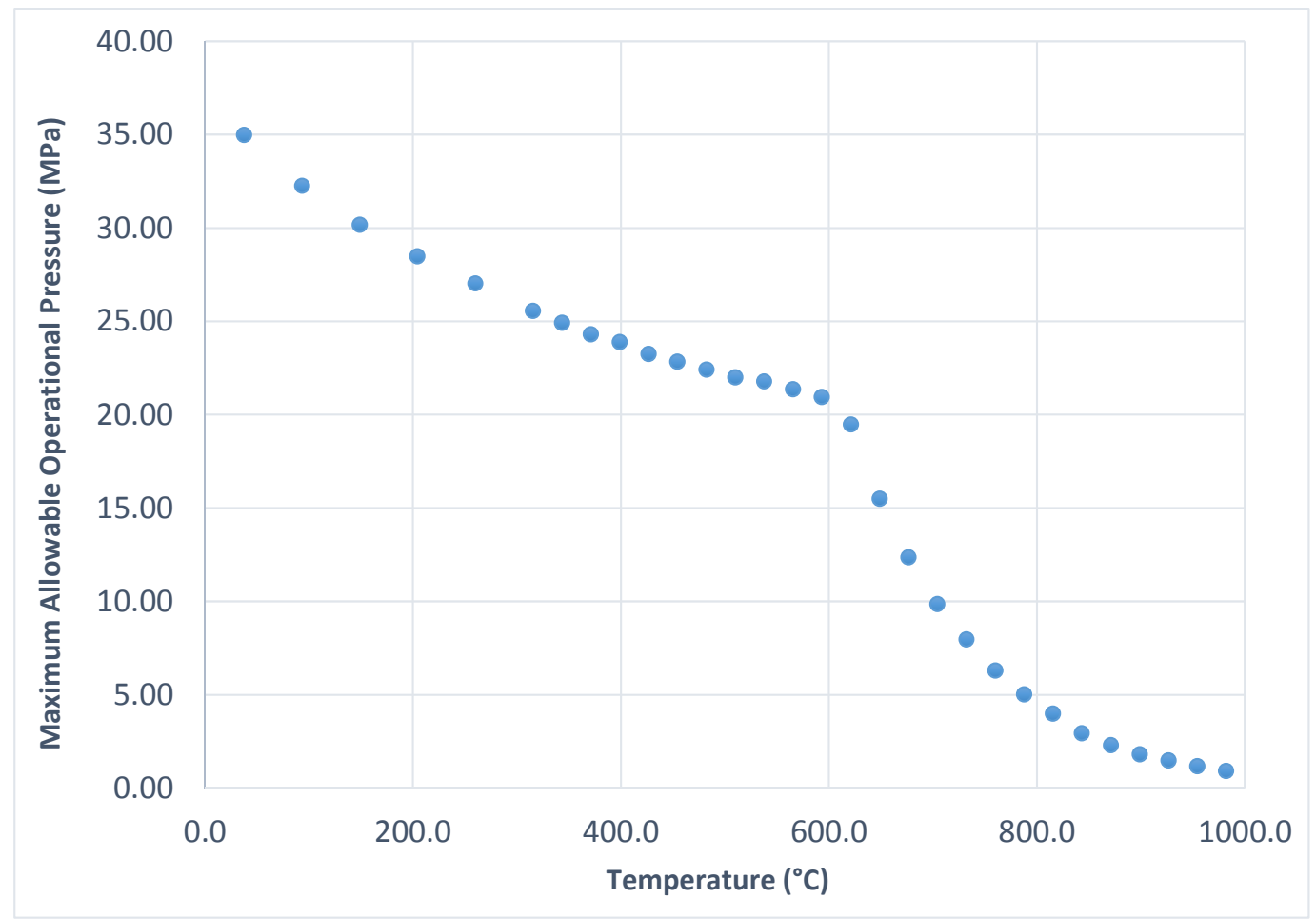

Figure 3. Alloy 800H NPS 2 SCH 160 maximum operational pipe pressure rating versus temperature.

The salt loop operates at low pressure, so standard schedule 40 NPS2 pipe or standard wall thickness tubing will be sufficient. In terms of material compatibility, considering cost and availability, Inconel 600 pipe may be the best choice. Other compatible alloys include $800 \mathrm{H}, 617$, Hastelloy N, or alloy 242 . However, these alloys may not be commercially available.

Piping for the water loop will be SS316, NPS2, schedule 160. The pressure rating for SS316, NPS2, schedule 160 at $350^{\circ} \mathrm{C}$ is $\sim 18.6 \mathrm{MPa}$, which is higher than the maximum loop operating pressure of $15 \mathrm{MPa}$. If NPS1 piping is used the pressure rating is close to $26 \mathrm{MPa}$ for schedule 160 and $17.8 \mathrm{MPa}$ for schedule 80.

\subsection{Pumps/Circulator}

Helium flow through the loop will be driven by a water-cooled centrifugal gas circulator rated for high-pressure (7 MPa) service, with a design flow rate up to 525 LPM at $7 \mathrm{MPa}$ (11,300 SLPM) and a loop pressure drop of $100 \mathrm{kPa}$. The circulator flow rate will be controlled by means of a variable-frequency drive coupled to the motor. The drive will provide an important functionality for the start-up and shut-down transients to allow for simulation of pump trip coast down curves [29]. In the interest of cost and feasibility, the helium circulator will be designed to operate with a maximum helium temperature below $100^{\circ} \mathrm{C}$. This requirement is the main driver for inclusion of the low-temperature section of the helium flow loop. Preliminary research regarding the availability and cost of a helium gas circulator to meet these specifications has been completed. The major challenges are the flow rate, the high operating pressure and the loop delta-P. The required circulator will likely be an engineered item, therefore it will be expensive. A preliminary quote from Barber Nichols indicated an approximate cost of $\$ 200 \mathrm{k}$.

Flow in the liquid salt loop will be driven by a vertical cantilever pump designed for service with salts. Operating conditions for the pump will be low pressure $(\sim 0.2 \mathrm{MPa})$ at a temperature of $420-440^{\circ} \mathrm{C}$. The required flow rate is $25 \mathrm{LPM}$. The required pressure head for this pump has not yet been determined. 
Liquid salt pumps are available commercially [30] for operation up to $600^{\circ} \mathrm{C}$ with large flow rates and delta-P values. Available pump materials include Inconel and Hastelloy.

The water flow loop also includes a low-temperature section for the pump. This pump will be designed for high-pressure operation $(15 \mathrm{MPa})$, providing a minimum flow rate of $8 \mathrm{LPM}$. Wetted parts will be stainless steel. The required pressure head for this pump has also not yet been determined.

All of the flow circulators/pumps will be powered by three-phase motors with variable-frequency drives for continuously variable speed and flow control.

\subsection{Instrumentation}

Process flow conditions in the three flow loops were discussed in Section 3.1. Conditions in some parts of these loops are very challenging for instrumentation. Basic process information required for all of the loops includes pressure, temperature, flow rate, and fluid chemistry. Additional instrumentation will be needed to measure differential pressure across components such as heat exchangers, heater power, and cooling water flow rates. A discussion of the particular instrumentation requirements and possible solutions is provided below for each of the three loops in the ARTIST facility

\subsubsection{Helium Loop}

\section{He Chemistry/Impurities and Moisture}

The baseline He loop chemistry is pure helium. However, even ultra-high-purity (UHP) helium contains trace impurities such as $\mathrm{H}_{2} \mathrm{O}, \mathrm{O}_{2}$, hydrocarbons, $\mathrm{CO}, \mathrm{CO}_{2}, \mathrm{~N}_{2}$, and $\mathrm{H}_{2}$. For UHP He, these impurities are in the low parts-per-million (ppm) range and the overall purity is specified as $99.999 \%$. However, additional impurities will enter the gas during loop operation, especially when high-temperature operation is initiated. Furthermore, some gases may have to be intentionally included as additives. For example, low levels of oxygen may be needed to maintain protective oxide scale on metallic components [31]. On the other hand, oxygen can corrode graphite in the vessel core, which can in turn release additional gases such as $\mathrm{CO}$ and $\mathrm{CO}_{2}$. These gases can subsequently form deposits on metallic components. Careful monitoring and control of these gases will be critical for successful long-term operation of the He loop. Monitoring is usually performed by withdrawing a gas sample from the low-temperature part of the loop for analysis using a gas chromatograph (GC) system.

\section{Flow rate}

Flow rate in the He loop will be measured in the low-temperature $\left(\sim 50^{\circ} \mathrm{C}\right)$ leg of the loop just downstream of the circulator. There are several options for measuring helium flow rate including thermal mass flow meter, coriolis meter, venturi meter, or vortex flow meter. For this closed-loop high-flow-rate helium flow system, one of the major costs will be the circulator and its cost will increase with loop pressure drop. Therefore, a low-pressure-drop flow measurement device is desired. The permanent pressure loss for vortex flow meters is quite low, and they provide excellent accuracy with pressure and temperature compensation to yield a true mass flow measurement. Commercial units that meet the pressure and temperature specifications for the helium flow loop are available from several vendors. Thermal mass flow meters with laminar flow elements will also be considered if the pressure drop is low enough. 


\section{Pressure: Absolute and Differential}

Pressure instrumentation for the helium loop will include several absolute pressure transducers, as indicated in Figure 2, plus several differential pressure transducers (dP cells). The differential transducers will be used primarily to measure pressure drop across the IHX and the recuperator. In some cases, differential pressure may be needed across the high-temperature test section as well. The differential transducers will be designed to measure relatively small pressure differences while operating at high absolute pressure. Each differential transducer assembly will include a dP cell manifold that allows zeroing of the cell at high absolute pressure.

\section{Temperature}

Temperature measurements for the helium loop will mostly be acquired using type K, stainless-steel or inconel-sheathed ungrounded 1/8- or 1/16-in. thermocouples inserted into the flow stream using compression fittings. Inconel sheathing will be used on the high-temperature portion of the loop. Type $\mathrm{K}$ thermocouples are rated for service up to $1260^{\circ} \mathrm{C}$.

\subsubsection{Liquid Salt Loop}

\section{$\underline{\text { Salt Chemistry Control }}$}

As described in Section 4.2.3, pretreatment of fluoride salts is necessary before introducing them to the flow loop, to remove oxygen, moisture, and other contaminants from the mixture. In addition, continuous monitoring and chemistry control will be necessary to monitor and remove any contaminants such as metal oxides that build up in the mixture as a result of interaction with loop materials or due to air or moisture ingress. Monitoring may include the use of a high-temperature electrochemical oxygen sensor based on yttria-stabilized zirconia (YSZ) or yttria-doped thoria (YDT) [32]. Development of a continuous chemistry monitoring system for the salt loop will be an important aspect of the loop design process.

\section{Flow Rate}

Most standard flow measurements include some kind of probe or sensor in direct contact with the fluid. Many of these are not appropriate for the liquid salt application. The measurement environment is very challenging both in terms of temperature and materials compatibility. Ultrasonic flow meters can be used for this application. Nonintrusive clamp-on ultrasonic flow meters are attached to the outside of a section of pipe with no fluid contact. These are available from several vendors. Wetted ultrasonic flow meters are permanently mounted on a spool piece; they provide higher accuracy [33], but appropriate materials must be selected for the pipe body and the sensor heads.

\section{Pressure and Delta-P}

A particularly important measurement for this loop will be the pressure drop across the IHX and the SHX. Pressure measurements will be challenging in the salt loop. The minimum requirement is that the transducer can operate at temperatures above the melting point of the salt. Melt pressure transducers operate by hydraulic transmission of pressure through a low-vapor-pressure incompressible liquid from a wetted diaphragm to a measurement diaphragm located away from the high temperature fluid [34]. NaK is commonly used as a hydraulic transmission fluid for high-temperature melt pressure transducers. It has a freezing point that is well below room temperature and a boiling point of $785^{\circ} \mathrm{C}$. NaK-filled melt pressure transducers operate over a temperature range up to $538^{\circ} \mathrm{C}$, which is an excellent match for the salt loop operating temperature range. Unfortunately, these transducers are generally only commercially available for high pressure ranges (lowest range is typically 0-10 MPa), whereas the salt loop will operate at low pressure $(\sim 0.2 \mathrm{MPa})$. The molten salt loop at ORNL uses a NaK-buffered pressure transducer that prevents overheating of the transducer electronics [19]. A direct diaphragm displacement pressure measurement probe has also been researched at ORNL and U. of TN for a molten salt loop application [35]. This probe incorporated a nickel diaphragm for a direct capacitance sensor-based 
measurement. Specification and selection of absolute and differential pressure transducers for the molten salt loop will be a design challenge to be addressed during the detailed design phase.

\section{Temperature}

For the liquid salt loop, type $\mathrm{K}$ inconel-sheathed ungrounded 1/8- or 1/16-in. thermocouples inserted into the flow stream using compression fittings will be used for most loop temperature measurements. Surface-mounted thermocouples will also be used to provide the process variable measurements required for feedback control of the heat-traced sections of piping and vessel walls in the salt loop.

\subsubsection{Water/Steam Loop}

\section{Chemistry Control}

The water flow loop includes a chemistry control section. Water chemistry control is critical for proper simulation of PWR conditions. Control of water chemistry parameters in an operating PWR is aimed at striking a balance between assuring the integrity of the primary system pressure boundary, the integrity of the fuel cladding, and to minimize out-of-core radiation fields [36]. For example, elevated $\mathrm{pH}$ can reduce out-of-core radiation fields, but can also lead to elevated lithium levels that can lead to alloy 600 cracking. Low $\mathrm{pH}$ values can lead to increased crud deposits. Operation at $\mathrm{pH}$ values of 6.9 - 7.4 is generally recommended. $\mathrm{pH}$ control is achieved by controlling the boric acid $\left(\mathrm{H}_{3} \mathrm{BO}_{3}\right)$ concentration $(\sim 500 \mathrm{ppm})$ and the lithium $(\mathrm{LiOH})$ concentration $(\sim 2.2 \mathrm{ppm})$. Corrosion experiments with simulated PWR water chemistry generally follow these guidelines [37]. In addition, minimization of dissolved oxygen to $<5 \mathrm{ppb}$ is desired. Small amounts of dissolved hydrogen can be included in PWR water to maintain reducing conditions and to eliminate radiolytically produced oxygen.

Instrumentation for the water loop will include in-line $\mathrm{pH}$ and dissolved oxygen sensors. Both of these sensors will be installed in the low-temperature part of the water loop. These sensors are available from a number of vendors with ranges that are suitable for this application.

\section{Flow Rate}

Flow rates in the water loop will be measured at full loop pressure (up to $15 \mathrm{MPa}$ ) and at low temperature $\left(\sim 50^{\circ} \mathrm{C}\right)$. The biggest challenge for this flow meter is the pressure, which is higher than the standard pressure rating on most off-the-shelf thermal or coriolis mass flow meters and controllers. GE does offer a high-pressure coriolis flow meter (RHM015) that is suitable for pressures up to $70 \mathrm{MPa}$, with a wide range of flow rates. Alternately, turbine flow meters are available from several manufacturers with standard pressure ratings of $35 \mathrm{MPa}$ or higher over a wide range of flow rates.

\section{Pressure and Delta-P}

Pressure instrumentation for the water loop will include several absolute pressure transducers, as indicated in Figure 2, plus several differential pressure transducers. The differential transducers will be used primarily to measure pressure drop across the SHX and the recuperator. In some cases, differential pressure may be needed across the high temperature test section as well. The differential transducers will be designed to measure relatively small pressure differences while operating at high absolute pressure. Each differential transducer assembly will include a dP cell manifold that allows zeroing of the cell at high absolute pressure.

\section{Temperature}

For the water loop, type $\mathrm{K}$ inconel-sheathed ungrounded 1/8- or 1/16-in. thermocouples inserted into the flow stream using compression fittings will be used for most loop temperature measurements. 


\subsection{Data Acquisition and Controls}

Data acquisition and instrument control for the multi-loop system will be accomplished through the development of a custom virtual instrument (vi) created in the LabVIEW (National Instruments) graphical programming environment. The vi communicates with multi-channel data acquisition hardware to read and store experimental data from all of the system instrumentation at a user-specified rate. The vi can also communicate with analog and digital output hardware to control loop operational parameters such as flow rates, heater power, and fluid temperature based on manual user input or built-in control algorithms. Experimental data will be stored according to the QA standard followed in the laboratory.

\subsection{Insulation}

Thermal insulation for the high-temperature sections of the He loop must be rated to at least $800^{\circ} \mathrm{C}$. Possibilities include alumina-silica or alumina-silica-zirconia fiber either in blanket or molded form. These materials are rated to $1250^{\circ}-1600^{\circ} \mathrm{C}$. Thermal conductivity increases with temperature. At $540^{\circ} \mathrm{C}$, the thermal conductivity is $\sim 0.1 \mathrm{~W} / \mathrm{m} \mathrm{K}$. An alternative is microporous insulation which is comprised of compacted inorganic metal oxide powders of surface area greater than $90 \mathrm{~m}^{2} / \mathrm{g}$, powdered inorganic infra-red opacifiers, and man-made or natural fibers or filaments. It is specified in ASTM standard C 1676 [38]. This material is characterized by the extremely low thermal conductivity at elevated temperatures $\left(0.03 \mathrm{~W} / \mathrm{m}-{ }^{\circ} \mathrm{C}\right.$ at $\left.650{ }^{\circ} \mathrm{C}\right)$. It is widely used in industry when high temperature resistance is needed with minimum thickness and weight. Its operating temperature limit reaches around $1,000^{\circ} \mathrm{C}$. It may be the most desirable insulation material for the high-temperature test section of the helium flow loop. Microtherm offers high-performance high-temperature insulation in rigid panels, flexible blanket, and molded form. The molded form is designed for fitting around pipes and other cylindrical shapes.

Lower temperature sections of piping can be insulated with more conventional insulation materials and forms. A loop heat loss estimation methodology has been developed in MATLAB [39] for assessing insulation types and thicknesses. This tool will be utilized in the final loop design process.

\subsection{Aspen/HYSYS Model of the ARTIST Facility}

A preliminary system analysis of the ARTIST facility was performed using Aspen/HYSYS. The flow sheet diagram is shown in Figure 4. Aspen/HYSYS inherently conserves mass and energy and accounts for fluid properties and their temperature dependence. This model was developed for validation of design calculations and for heat exchanger sizing. It will also be useful for future performance characterization of loop components including heat exchanger effectiveness and pressure drop. Results of the initial design calculations are presented in Table 4. . The state points are indicated numerically in Figure 4. State points 1-8 represent conditions in the He loop. State points 9-21 represent conditions in the liquid salt loop, and state points 22-34 are for the water loop. Note that the design flow rate in the liquid salt loop is $1 \mathrm{~kg} / \mathrm{s}$, with a $50^{\circ} \mathrm{C}$ temperature drop across the IHX. This specification determines the heat duty for both the IHX and the SHX. Heat exchanger operating parameters are shown in Table for all loop heat exchangers. Fluid inlet and outlet temperatures, flow rates, and heat duties are also listed. 


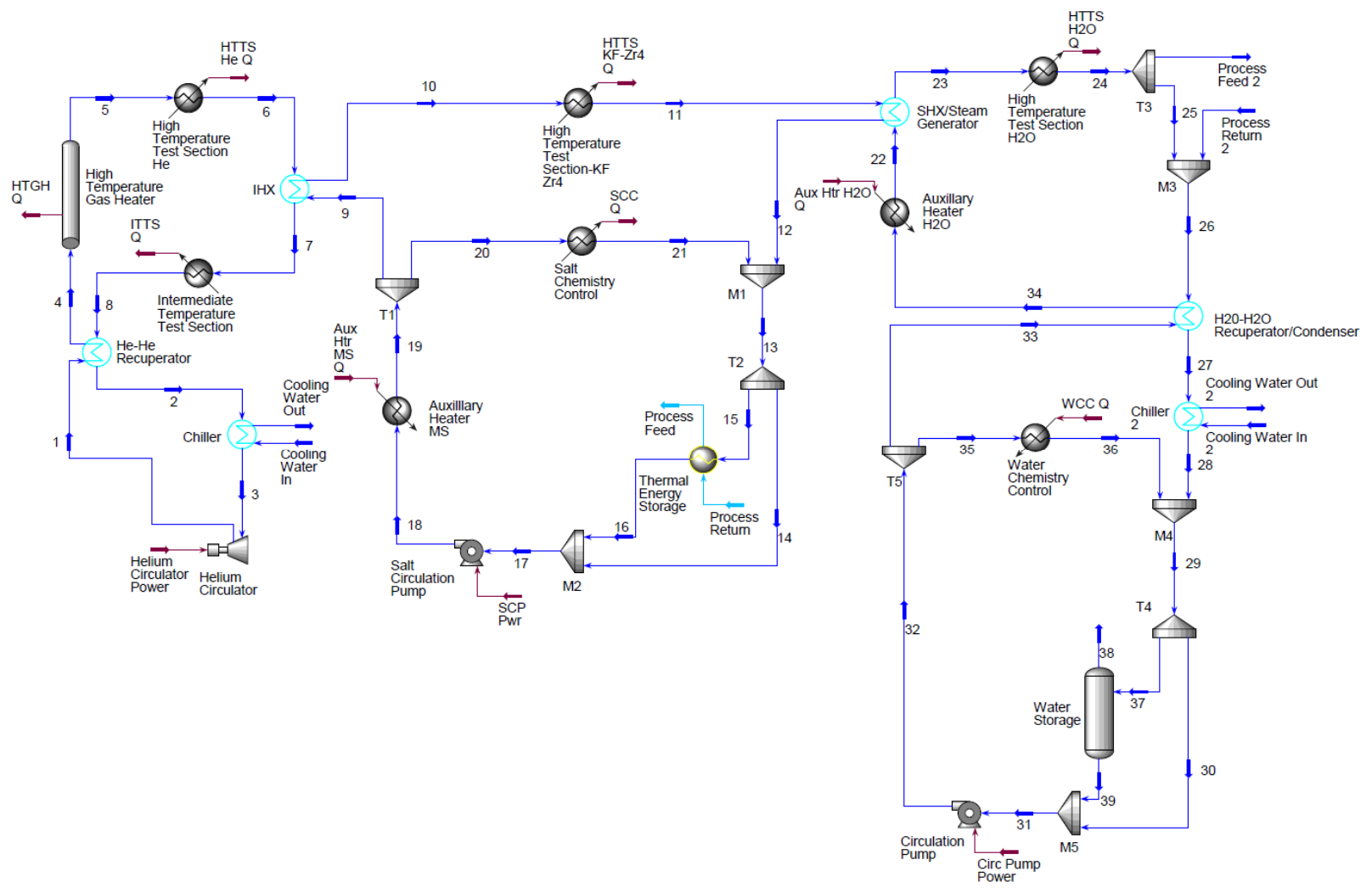

Figure 4. Aspen/HYSYS process flow diagram for system analysis of the ARTIST facility. 
Table 4. Loop design operating conditions based on Aspen/HYSYS model.

\begin{tabular}{|c|c|c|c|c|c|}
\hline State Point & $\mathrm{T}(\mathrm{C})$ & $\mathrm{P}(\mathrm{MPa})$ & $\begin{array}{c}\text { Mass Flow } \\
(\mathrm{kg} / \mathrm{s})\end{array}$ & $\begin{array}{l}\text { Density } \\
(\mathrm{kg} / \mathrm{m} 3)\end{array}$ & $\begin{array}{c}\text { Volume Flow } \\
(\mathrm{L} / \mathrm{min})\end{array}$ \\
\hline 1 & 50 & 7.143 & 0.0337 & 10.3 & 196.4 \\
\hline 2 & 100.1 & 6.492 & 0.0337 & 8.156 & 248.0 \\
\hline 3 & 30.66 & 6.362 & 0.0337 & 9.776 & 206.9 \\
\hline 4 & 400 & 7 & 0.0337 & 4.924 & 410.8 \\
\hline 5 & 750 & 7 & 0.0337 & 3.257 & 621.0 \\
\hline 6 & 750.1 & 6.86 & 0.0337 & 3.192 & 633.6 \\
\hline 7 & 450 & 6.76 & 0.0337 & 4.434 & 456.2 \\
\hline 8 & 450.1 & 6.625 & 0.0337 & 4.346 & 465.4 \\
\hline 9 & 430 & 0.2041 & 1 & 3035 & 19.78 \\
\hline 10 & 480 & 0.2 & 1 & 2990 & 20.07 \\
\hline 11 & 480 & 0.196 & 1 & 2990 & 20.07 \\
\hline 12 & 430 & 0.1921 & 1 & 3035 & 19.78 \\
\hline 13 & 430 & 0.1921 & 1 & 3035 & 19.78 \\
\hline 14 & 430 & 0.1921 & 1 & 3035 & 19.78 \\
\hline 17 & 430 & 0.1921 & 1 & 3035 & 19.78 \\
\hline 18 & 430 & 0.2082 & 1 & 3035 & 19.78 \\
\hline 19 & 430 & 0.2041 & 1 & 3035 & 19.78 \\
\hline 22 & 275 & 15.31 & 0.1893 & 772.8 & 14.7 \\
\hline 23 & 325 & 15 & 0.1893 & 665.2 & 17.08 \\
\hline 24 & 324.9 & 14.7 & 0.1893 & 664.5 & 17.09 \\
\hline 25 & 324.9 & 14.7 & 0.1893 & 664.5 & 17.09 \\
\hline 26 & 324.9 & 14.7 & 0.1893 & 664.5 & 17.09 \\
\hline 27 & 116.9 & 14.41 & 0.1893 & 952.5 & 11.92 \\
\hline 28 & 49.79 & 14.12 & 0.1893 & 994.1 & 11.43 \\
\hline 29 & 49.79 & 14.12 & 0.1893 & 994.1 & 11.43 \\
\hline 30 & 49.79 & 14.12 & 0.1893 & 994.1 & 11.43 \\
\hline 31 & 49.79 & 14.12 & 0.1893 & 994.1 & 11.43 \\
\hline 32 & 50 & 15.94 & 0.1893 & 994.8 & 11.42 \\
\hline 33 & 50 & 15.94 & 0.1893 & 994.8 & 11.42 \\
\hline 34 & 275 & 15.62 & 0.1893 & 773.2 & 14.69 \\
\hline
\end{tabular}


Table 5. Heat exchanger operating parameters.

\begin{tabular}{|c|c|c|c|c|c|c|c|}
\hline $\begin{array}{c}\text { Heat } \\
\text { Exchanger }\end{array}$ & $\begin{array}{c}\text { Fluid, } \\
\text { side A }\end{array}$ & $\begin{array}{c}\text { Fluid, } \\
\text { side B }\end{array}$ & $\begin{array}{c}\text { Tin/Tout, } \\
\text { side A } \\
\left({ }^{\circ} \mathrm{C}\right)\end{array}$ & $\begin{array}{c}\text { Tin/Tout, } \\
\text { side B } \\
\left({ }^{\circ} \mathrm{C}\right)\end{array}$ & $\begin{array}{c}\text { Mass flow } \\
\text { rate, side A } \\
(\mathrm{kg} / \mathrm{s})\end{array}$ & $\begin{array}{c}\text { Mass flow } \\
\text { rate, side B } \\
(\mathrm{kg} / \mathrm{s})\end{array}$ & $\begin{array}{c}\mathrm{Heat} \text { duty } \\
(\mathrm{kW})\end{array}$ \\
\hline $\begin{array}{c}\mathrm{He}-\mathrm{He} \\
\text { Recuperator }\end{array}$ & $\mathrm{He}$ & $\mathrm{He}$ & $50 / 400$ & $450 / 100$ & $\mathrm{He} / .0337$ & $\mathrm{He} / .0337$ & 61.3 \\
\hline $\mathrm{IHX}$ & $\mathrm{He}$ & $\begin{array}{c}\mathrm{KF}-\mathrm{Zr} \\
\mathrm{F}_{4}\end{array}$ & $750 / 450$ & $430 / 480$ & $\mathrm{He} / .0337$ & $\mathrm{KF}-\mathrm{ZrF}_{4} / 1.0$ & 52.6 \\
\hline $\mathrm{He}$ Chiller & $\mathrm{He}$ & $\mathrm{H}_{2} \mathrm{O}$ & $100 / 31$ & $25 / 40$ & $\mathrm{He} / .0337$ & $\mathrm{H}_{2} \mathrm{O} / .1945$ & 12.2 \\
\hline $\mathrm{SHX}$ & $\begin{array}{c}\mathrm{KF}-\mathrm{Zr} \\
\mathrm{F}_{4}\end{array}$ & $\mathrm{H}_{2} \mathrm{O}$ & $480 / 430$ & $275 / 325$ & $\mathrm{KF}-\mathrm{ZrF}_{4} / 1.0$ & $\mathrm{H}_{2} \mathrm{O} / .1893$ & 52.6 \\
\hline $\begin{array}{c}\mathrm{H}_{2} \mathrm{O} \\
\text { recuperator }\end{array}$ & $\begin{array}{c}\mathrm{H}_{2} \mathrm{O} \\
\mathrm{H}_{2} \mathrm{O}\end{array}$ & $50 / 275$ & $325 / 117$ & $\mathrm{H}_{2} \mathrm{O} / .1893$ & $\mathrm{H}_{2} \mathrm{O} / .1893$ & 186 \\
\hline $\mathrm{H}_{2} \mathrm{O}$ Chiller & $\mathrm{H}_{2} \mathrm{O}$ & $\mathrm{H}_{2} \mathrm{O}$ & $117 / 50$ & $20 / 50$ & $\mathrm{H}_{2} \mathrm{O} / .1893$ & $\mathrm{H}_{2} \mathrm{O} / .4227$ & 53 \\
\hline
\end{tabular}

\subsection{Preliminary 3-D CAD Model of the ARTIST facility}

A three-dimensional (3-D) computer-aided design (CAD) model of the ARTIST experimental test facility has been developed using Pro-Engineering software. The CAD model includes all of the major facility components and piping. A rendering of the model is provided in Figure 5, with all of the components labeled. The facility is shown mounted on a large skid, measuring $4.9 \mathrm{~m}(16 \mathrm{ft}) \times 9.1 \mathrm{~m}$ (30 ft). The highest component is at the $7.0 \mathrm{~m}(23 \mathrm{ft})$ elevation. Components in the helium loop are designated with the He- abbreviation, salt loop components with the LS- abbreviation, and water/steam loop components with the WS- abbreviation. This labeling system is also used in the list of major components presented in Table 6. Renderings of the individual helium (He), liquid salt (LS), and water/steam (WS) loops are displayed separately in Figure 6, Figure 7 and Figure 8, respectively. Pipe supports and insulation are not shown in these figures. Each component is shown to scale according to the current status of the design. Notable features of the high-pressure helium and water loops include the large flanges on the piping sections. The low-temperature sections of the He loop require class 600 flanges and NPS 2, schedule 160 piping. The high-temperature section of the He loop requires class 2500 flanges. Due to its higher pressure, the water/steam loop utilizes NPS 2, schedule 160 piping and class 2500 valves and flanges throughout. As an alternative to large flanges, the use of Grayloc connectors will also be examined.

The geometry of the He-He recuperator and the IHX shown in Figure 6 is based on a baseline PCHE design, sized to support the design helium flow rate and the required heat duty. The exact dimensions of these heat exchangers may change, depending on the final design details and the vendor selected. The high-temperature gas heater shown in Figure 6 is based on a Watlow circulation heater with alloy $800 / 800 \mathrm{H}$ sheaths and ANSI 600 class pressure rating. The valving arrangement shown in Figure 6, downstream of the high-temperature gas heater, allows for bypass of the high-temperature test section. Three valves are shown instead of a single three-way valve because a three-way valve rated for these temperatures and pressures has not yet been identified. The high-temperature and intermediatetemperature helium test sections as shown in Figure 6 are designed to accommodate small tube bundles or other geometries of interest. The instrumentation in the test sections and loops could potentially serve the dual purpose of measuring test parameters and demonstrating new high-resolution advanced instrumentation and control equipment in challenging environments. The test sections will be custom-designed components and may be built in a range of sizes. The test sections shown in Figure 6, 
Figure 7, and Figure 8 have an outer diameter of $15.2 \mathrm{~cm}(6 \mathrm{in}$.$) over a length of 0.76 \mathrm{~m}$, with a total length of $1.22 \mathrm{~m}$ between flanges.

As mentioned in Section 3.1, helium flow through the loop will be driven by a water-cooled centrifugal gas circulator rated for high-pressure service, with a design flow rate up to $525 \mathrm{LPM}$ at $7 \mathrm{MPa}$ $(11,300$ SLPM) and a loop pressure drop of $100 \mathrm{kPa}$. The circulator flow rate will be controlled by means of a variable-frequency drive coupled to the motor. The helium circulator will be designed to operate with a maximum helium temperature of $100^{\circ} \mathrm{C}$. The circulator geometry shown in Figure 6 is based on information received from Barber-Nichols for gas circulators with similar requirements. The He chiller is shown as two coiled tube-in-tube counter-flow heat exchangers arranged in parallel. The use of two parallel chillers provides the required flow area with off-the-shelf units. The vacuum pump for removing air from the loop is also shown.

Details of the salt loop geometry are presented in Figure 7. A list of major components and specifications for the salt loop is given in the middle section of Table 6 . The largest component of the salt loop is the storage/drain tank. The current tank design size is $1 \mathrm{~m}$ diameter and $2 \mathrm{~m}$ high. This size is large enough to accommodate all of the salt in the loop and in the thermal energy storage system, while maintaining a high enough liquid salt level to avoid any risk of gas entrainment into the pump. The salt storage/drain tank is not a pressure vessel because the salt loop operating pressure will be only slightly elevated above ambient pressure. The salt pump is a vertical cantilever pump, shown with a geometry based on a design for liquid salts available from Nagle. The ultrasonic flow meter shown in Figure 7 is based on the Panaflow design from GE. The auxiliary heater is based on a Watlow circulation heater design. We have had several design interactions with Watlow technical support staff. They are confident that this heater will be able to meet the specifications with the liquid salt working fluid, provided the appropriate heater element cladding materials are used, either alloy 600 or $800 \mathrm{H}$, which are available. The SHX in Figure 7 is shown as the same size as the IHX.

The thermal energy storage tank in Figure 7 is shown with a diameter of $0.75 \mathrm{~m}$ and a height of $1.5 \mathrm{~m}$, providing a volume of $660 \mathrm{~L}$ and a thermal capacity of $978 \mathrm{MJ}$ or $272 \mathrm{~kW}-\mathrm{hr}_{\text {th }}$, based on the latent heat of fusion for KF. It will be designed for operation as a high-temperature, phase-change, thermal energy storage system, using the fluoride salt working fluid of the salt loop as the phase-change material.

Details of the 3-D model of the water/steam loop are presented in Figure 8. The water/steam loop is designed to operate at PWR conditions. The water storage and deaeration tank is sized to hold all of the purified water in the loop. It can be isolated from the flow loop and therefore it will not be designed for full loop pressure. Charging and draining of the loop will be performed at atmospheric pressure. As shown in the figure, the water storage tank has a diameter of $0.76 \mathrm{~m}$ and a height of $1.5 \mathrm{~m}$, with an internal volume of $695 \mathrm{~L}$, which is about 2.7 times larger than the estimated total loop water volume, therefore providing storage for excess purified water plus a gas space for air removal. The water circulation pump will operate at $15 \mathrm{MPa}$, providing a loop flow rate of at least $350 \mathrm{~kg} / \mathrm{hr}(2.5 \mathrm{gpm})$ against a loop pressure drop of $20 \mathrm{kPa}$. Loop pressure will be set and maintained using a bladder accumulator pressurized by nitrogen gas. The commercially available accumulator is $0.24 \mathrm{~m}$ in diameter and $2.0 \mathrm{~m}$ high. The auxiliary heater will be a custom-engineered circulation heater housed in a class-2500 pressure vessel. The water chiller will consist of two parallel, tube-in-tube, water-cooled, counterflow heat exchangers rated for $15 \mathrm{MPa}$ service. Depending on the laboratory capabilities, the cooling water will be either once-through tap water or circulated house water cooled by a facility chiller. 


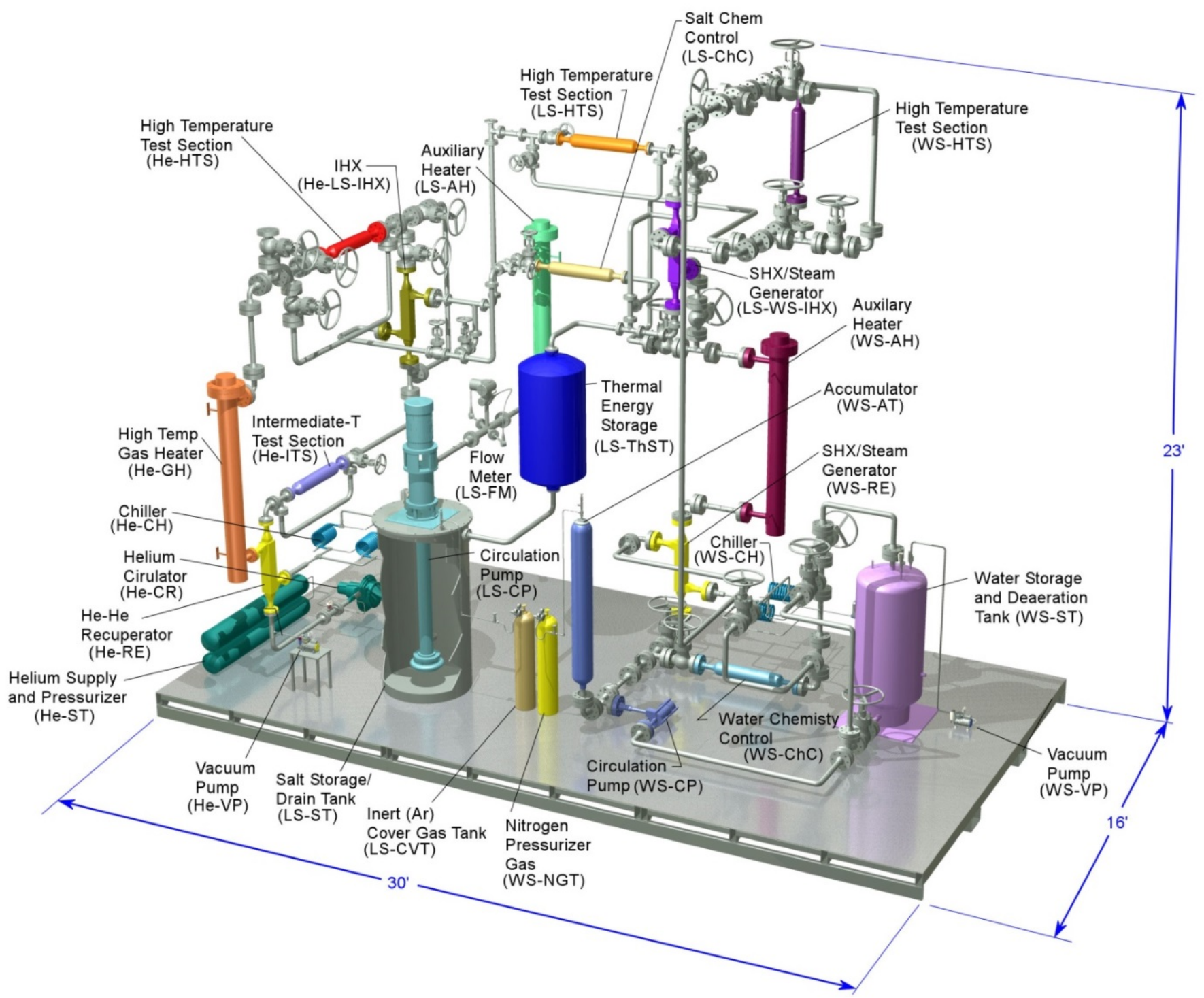

Figure 5. Overview 3-D CAD model of the ARTIST facility. 


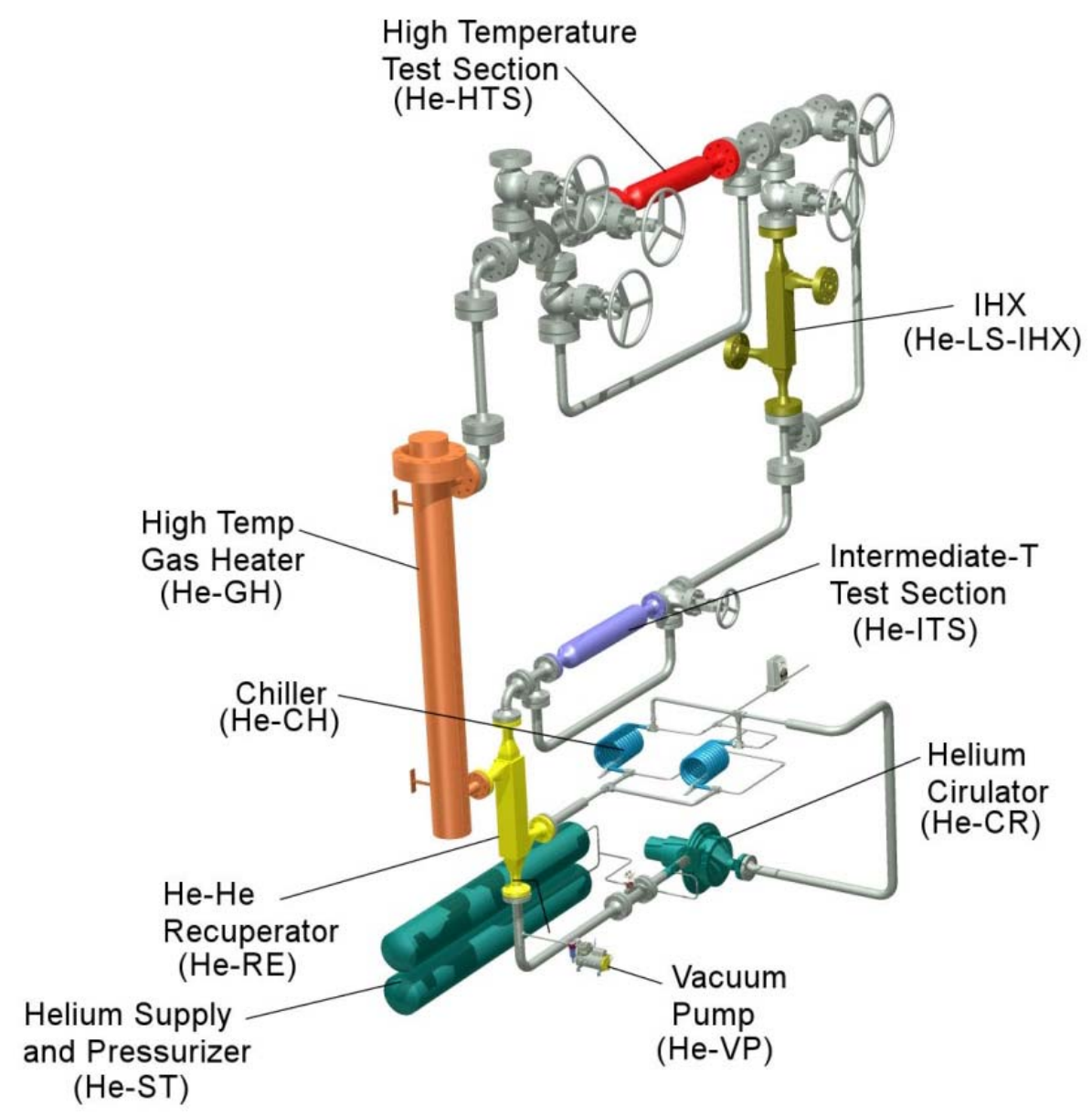

Figure 6. 3-D model of the helium loop. 


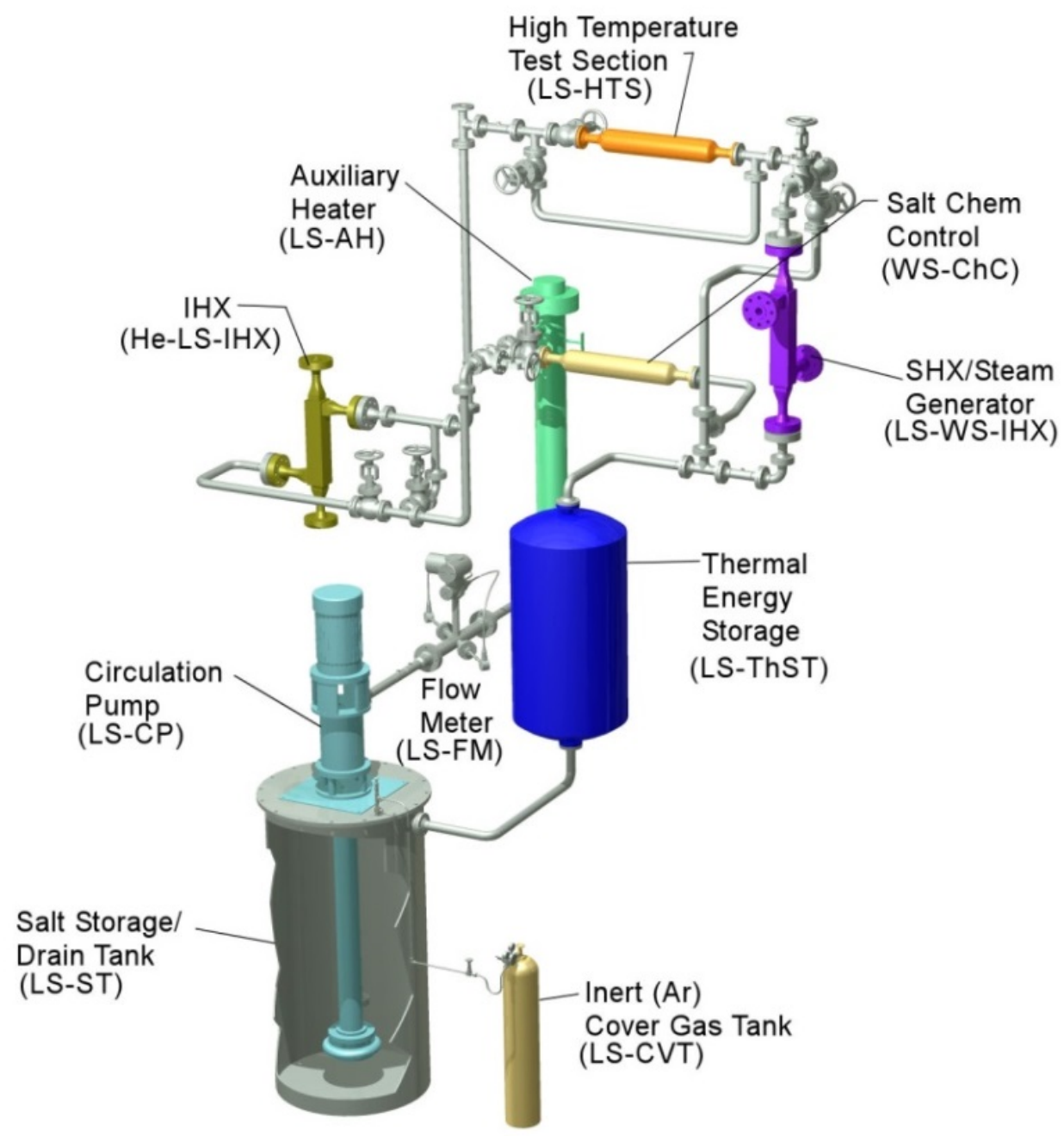

Figure 7. 3-D model of the liquid salt loop. 


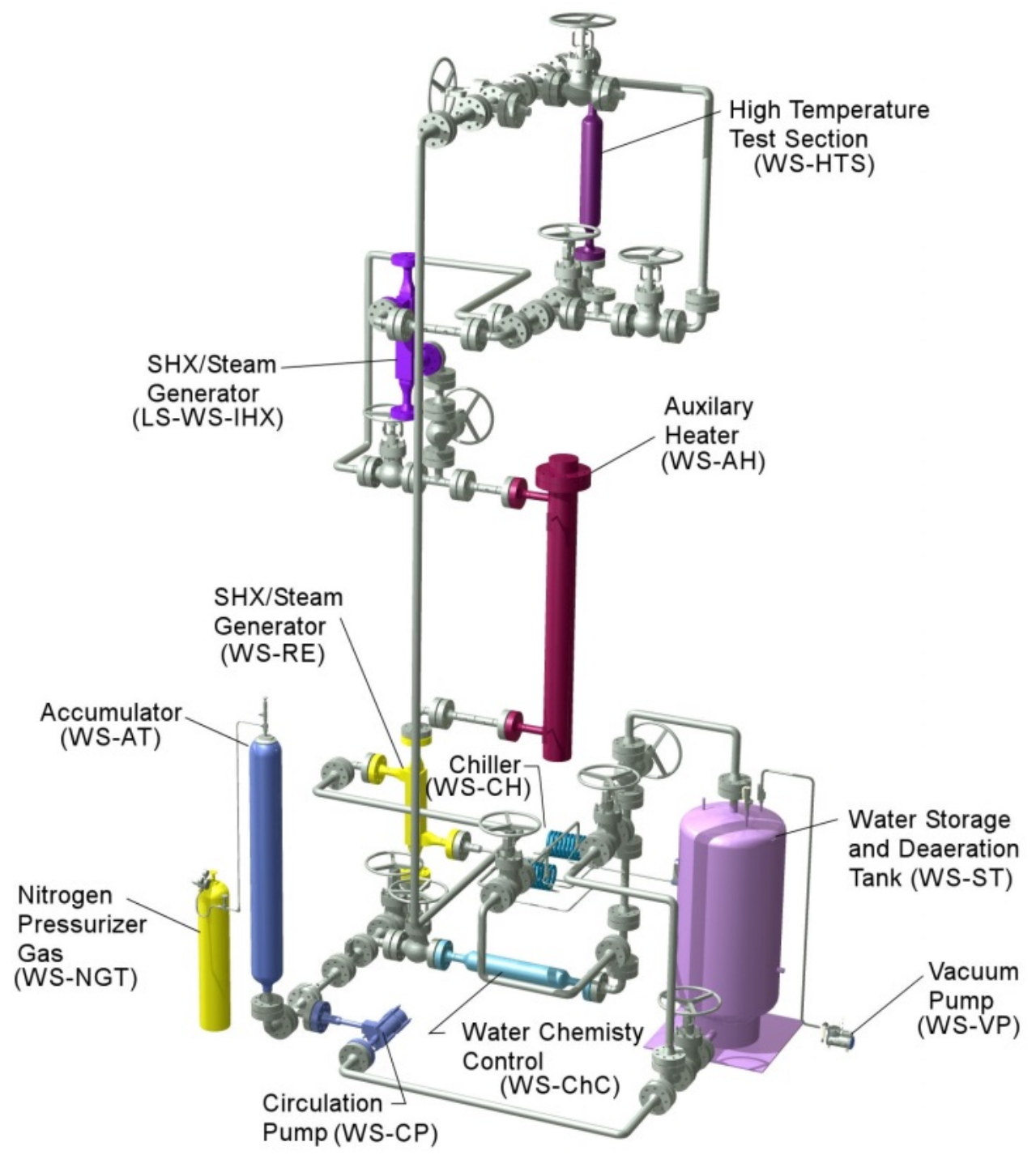

Figure 8. 3-D model of the water/steam loop. 
Table 6. ARTIST facility list of major components.

\begin{tabular}{|c|c|c|c|c|c|}
\hline & Helium Loop & & & & \\
\hline & Component Type & $\begin{array}{l}\text { Component } \\
\text { Label }\end{array}$ & $\begin{array}{l}\text { Number } \\
\text { Required } \\
\end{array}$ & Specification & Purpose \\
\hline 1 & $\begin{array}{l}\text { Helium Supply Tank } \\
\text { (Gas Bottle) }\end{array}$ & He-ST & TBD & Standard & $\begin{array}{l}\text { primary loop } \mathrm{He} \\
\text { supply }\end{array}$ \\
\hline 2 & Helium Circulator & $\mathrm{He}-\mathrm{CR}$ & 1 & $\begin{array}{l}12000 \text { SLPM, }(525 \\
\text { LPM @7 MPa), with } \\
100 \mathrm{kPa} \text { pressure } \\
\text { differential. }\end{array}$ & $\begin{array}{l}\text { Circulate } \mathrm{He} \text { in the } \\
\text { loop }\end{array}$ \\
\hline 2.1 & $\begin{array}{l}\text { Blower/Circulator Motor } \\
\text { and variable-speed drive }\end{array}$ & He-CRM & 1 & Power - 7.5 HP & $\begin{array}{l}\text { Provide the driving } \\
\text { force for the circulator }\end{array}$ \\
\hline 3 & Vacuum Pump & $\mathrm{He}-\mathrm{VP}$ & 1 & $10^{-3}$ Torr & $\begin{array}{l}\text { Air removal during } \\
\text { charging of He loop }\end{array}$ \\
\hline 4 & He-He Recuperator & He-RE & 1 & $54 \mathrm{~kW}, 7 \mathrm{MPa}, 400^{\circ} \mathrm{C}$ & $\begin{array}{l}\text { heat recuperation in } \\
\text { He loop, PCHE }\end{array}$ \\
\hline 5 & $\begin{array}{l}\text { High Temperature Gas } \\
\text { Heater }\end{array}$ & $\mathrm{He}-\mathrm{GH}$ & 1 & $\begin{array}{l}60.8 \mathrm{~kW} \text { gas } \\
\text { circulation heater, } \\
\text { outlet Temp up to } \\
750^{\circ} \mathrm{C} \text {. }\end{array}$ & $\begin{array}{l}\text { primary heat source in } \\
\text { multi-loop facility }\end{array}$ \\
\hline 6 & $\begin{array}{l}\text { High-Temperature Test } \\
\text { Section }\end{array}$ & He-HTS & 1 & $7 \mathrm{MPa}, 750^{\circ} \mathrm{C}$ & $\begin{array}{l}\text { Thermal hydraulics } \\
\text { and material testing } \\
\text { (such as: creep) at } \\
\text { prototypical } \\
\text { temperature and } \\
\text { pressure }\end{array}$ \\
\hline 7 & $\begin{array}{l}\text { Intermediate- } \\
\text { Temperature Test Section }\end{array}$ & He-ITS & 1 & $6.8 \mathrm{MPa}, 450^{\circ} \mathrm{C}$ & $\begin{array}{l}\text { Thermal hydraulics } \\
\text { and material testing at } \\
\text { specified temperature } \\
\text { and pressure }\end{array}$ \\
\hline 8 & $\begin{array}{l}\text { Intermediate Heat } \\
\text { Exchanger (IHX) }\end{array}$ & He-LS-IHX & 1 & $\begin{array}{l}60 \mathrm{~kW}, \mathrm{PCHE}, \mathrm{He} @ \\
7 \mathrm{MPa} \text { and Liquid Salt } \\
(\mathrm{LS}) @ 0.2 \mathrm{MPa}\end{array}$ & $\begin{array}{l}\text { Heat exchanger testing } \\
\text { at prototypical } \\
\text { conditions; V\&V }\end{array}$ \\
\hline 9 & Chiller & $\mathrm{He}-\mathrm{CH}$ & 1 & $\begin{array}{l}8.2 \mathrm{~kW}, 6.9 \mathrm{MPa}(\mathrm{He}) / \\
0.1 \mathrm{MPa}\left(\mathrm{H}_{2} \mathrm{O}\right)\end{array}$ & $\begin{array}{l}\text { std tube-in-tube } \\
\text { counter-flow type }\end{array}$ \\
\hline 10 & Valves & & & $\begin{array}{l}\text { gate valves; class } \\
2500 \text { in high-T } \\
\text { sections, class } 600 \text { in } \\
\text { low-T sections }\end{array}$ & \\
\hline 10.1 & 3-way, High Temp Valve & He-HTV & 6 & $7 \mathrm{MPa}, 750^{\circ} \mathrm{C}$ & $\begin{array}{l}\text { Control flow direction } \\
\text { and flow rate }\end{array}$ \\
\hline 10.2 & $\begin{array}{l}\text { 3-way, Medium Temp } \\
\text { Valve }\end{array}$ & He-MTV & 2 & $7 \mathrm{MPa}, 400^{\circ} \mathrm{C}$ & $\begin{array}{l}\text { Control flow direction } \\
\text { and flow rate }\end{array}$ \\
\hline
\end{tabular}


Table 6. (continued)

\begin{tabular}{|c|c|c|c|c|c|}
\hline 10.3 & 3-way, Low Temp Valve & He-LTV & 3 & $7 \mathrm{MPa}, 50^{\circ} \mathrm{C}$ & $\begin{array}{l}\text { Control flow direction } \\
\text { and flow rate }\end{array}$ \\
\hline 10.4 & Check Valve & $\mathrm{He}-\mathrm{CV}$ & 1 & TBD & \\
\hline 11 & Pipe Sections & He-PS & & $\begin{array}{l}800 \mathrm{H}, \text { NPS 2, Sch } \\
160\end{array}$ & $\begin{array}{l}\text { Construction material } \\
\text { for the He loop }\end{array}$ \\
\hline 12 & Flanges & $\mathrm{He}-\mathrm{FL}$ & & $\begin{array}{l}\text { class } 2500 \text { in high- } \\
\text { temperature sections; } \\
\text { class } 600 \text { in low- } \\
\text { temperature sections }\end{array}$ & mating of components \\
\hline 14 & Thermal Insulation & He-TI & & $\begin{array}{l}\text { TBD, (Temp Req: } \\
\left.400-750^{\circ} \mathrm{C}\right)\end{array}$ & $\begin{array}{l}\text { minimize loop heat } \\
\text { loss }\end{array}$ \\
\hline & \multicolumn{5}{|l|}{ Liquid Salt Loop } \\
\hline 15 & $\begin{array}{l}\text { Inert (Ar) Cover Gas } \\
\text { Tank }\end{array}$ & LS-CVT & & UHP & $\begin{array}{l}\text { prevent air ingress and } \\
\text { oxidation }\end{array}$ \\
\hline 16 & Salt Storage/Drain Tank & LS-ST & & $\begin{array}{l}\mathrm{D}=1 \mathrm{~m}, \mathrm{H}=2 \mathrm{~m} \\
\mathrm{~V}=1.67 \mathrm{~m}^{3}\end{array}$ & $\begin{array}{l}\text { hold entire contents of } \\
\text { salt loop and thermal } \\
\text { energy storage system }\end{array}$ \\
\hline 17 & Circulation Pump & LS-CP & 1 & $\begin{array}{l}1 \mathrm{~kg} / \mathrm{s}, 25 \mathrm{LPM}, 6 \\
\mathrm{GPM} @ 420^{\circ} \mathrm{C}, 5 \mathrm{HP} \\
\text { (Cantilever Sump } \\
\text { Pump, SS316, for all } \\
\text { wetted parts) }\end{array}$ & $\begin{array}{l}\text { liquid salt prime } \\
\text { mover }\end{array}$ \\
\hline 18 & Auxiliary Heater & LS-AH & 1 & $75 \mathrm{~kW}$ & $\begin{array}{l}\text { primary heat addition } \\
\text { for independent } \\
\text { operation of salt loop } \\
\text { (i.e., when IHX is } \\
\text { bypassed) }\end{array}$ \\
\hline 19 & $\begin{array}{l}\text { Liquid Salt High Temp } \\
\text { Test Section }\end{array}$ & LS-HTS & 1 & $0.2 \mathrm{MPa}, 480^{\circ} \mathrm{C}$ & $\begin{array}{l}\text { Thermal hydraulics } \\
\text { and materials testing } \\
\text { (mainly corrosion) at } \\
\text { prototypical } \\
\text { temperature and } \\
\text { pressure }\end{array}$ \\
\hline 20 & $\begin{array}{l}\text { Sec. Heat Exchanger } \\
(\mathrm{SHX}) / \text { Steam } \\
\text { Generator }\end{array}$ & $\begin{array}{l}\text { LS-Wa } \\
(\mathrm{H} 2 \mathrm{O})-\mathrm{IHX}\end{array}$ & 1 & $\begin{array}{l}\text { 60kW, PCHE, Liquid } \\
\text { Salt (LS)@0.2MPa / } \\
\text { Water (Wa)@15 } \\
\mathrm{MPa}\end{array}$ & $\begin{array}{l}\text { Heat Exchanger } \\
\text { Testing in the } \\
\text { prototypical } \\
\text { environment; V\&V }\end{array}$ \\
\hline 21 & $\begin{array}{l}\text { Liquid Salt Chemistry } \\
\text { Control }\end{array}$ & LS-ChC & 1 & $0.2 \mathrm{MPa}, 430^{\circ} \mathrm{C}$ & $\begin{array}{l}\text { study effects of } \\
\text { impurities; maintain } \\
\text { the purity level of LS } \\
\text { in the loop }\end{array}$ \\
\hline 22 & $\begin{array}{l}\text { Thermal Energy Storage } \\
\text { Tank }\end{array}$ & LS-ThST & 1 & $\begin{array}{l}\mathrm{D}=0.75 \mathrm{~m}, \mathrm{H}=1.5 \mathrm{~m}, \\
\mathrm{~V}=663 \mathrm{~L}, 978 \mathrm{MJ}\end{array}$ & $\begin{array}{l}\text { phase-change thermal } \\
\text { energy storage with } \\
\text { salt PCM }\end{array}$ \\
\hline
\end{tabular}


Table 6. (continued)

\begin{tabular}{|c|c|c|c|c|c|}
\hline 23 & Thermal Insulation & LS-TI & & $\begin{array}{l}\text { TBD, (Temp Req: } \\
\left.390-500^{\circ} \mathrm{C}\right)\end{array}$ & $\begin{array}{l}\text { minimize loop heat } \\
\text { loss }\end{array}$ \\
\hline 24 & Salt Tank Heater & LS-TH & 1 & $75 \mathrm{~kW}$ & $\begin{array}{l}\text { heat salt from frozen } \\
\text { state to } 430^{\circ} \mathrm{C}\end{array}$ \\
\hline 25 & Valves & & & $\begin{array}{l}0.2 \mathrm{MPa}, 550^{\circ} \mathrm{C} \text {, class } \\
600\end{array}$ & $\begin{array}{l}\text { Specify for } 550^{\circ} \mathrm{C} \text {, } \\
\text { providing high temp } \\
\text { margin, also if other } \\
\text { high temp salt is used, } \\
\text { same valves could be } \\
\text { utilized }\end{array}$ \\
\hline 25.1 & 3-way, High Temp Valve & LS-HTV & & $\begin{array}{l}0.2 \mathrm{MPa}, 550^{\circ} \mathrm{C} \text {, class } \\
600\end{array}$ & \\
\hline 25.2 & Pressure Release Valve & LS-PRV & 2 & $\begin{array}{l}0.2 \mathrm{MPa}, 550^{\circ} \mathrm{C} \text {, class } \\
600\end{array}$ & \\
\hline 25.3 & Check Valve & LS-CV & 1 & $\begin{array}{l}0.2 \mathrm{MPa}, 550^{\circ} \mathrm{C} \text {, class } \\
600\end{array}$ & \\
\hline 26 & Piping & & & $0.2 \mathrm{MPa}, 550^{\circ} \mathrm{C}$ & $\begin{array}{l}\text { Inconel } 600 \text { is } \\
\text { recommended, based } \\
\text { on corrosion resistance } \\
\text { and cost; other } \\
\text { possible alloys are } \\
800 \mathrm{H}, 617, \mathrm{~N} \text {, and } \\
242 ; \text { schedule } 40 \text { pipe } \\
\text { or standard-wall } \\
\text { tubing should be } \\
\text { suitable (low pressure) }\end{array}$ \\
\hline 27 & Heat Trace & $\mathrm{HT}$ & & $430^{\circ} \mathrm{C}$ & $\begin{array}{l}\text { Applied to the entire } \\
\text { loop to prevent local } \\
\text { cold spots and } \\
\text { possibile freezing of } \\
\text { salt }\end{array}$ \\
\hline & \multicolumn{5}{|c|}{ Water/Steam Loop } \\
\hline 28 & Nitrogen Gas Cylinder & WS-NGT & 1 & $15 \mathrm{MPa}$ & $\begin{array}{l}\text { pressurizer for water } \\
\text { loop }\end{array}$ \\
\hline 29 & Accumulator Tank & WS-AT & 1 & $\begin{array}{l}\mathrm{D}=9.6 \text { in, } \mathrm{H}=78 \text { in, } \\
\text { bladder accumulator }\end{array}$ & $\begin{array}{l}\text { pressurizer for water } \\
\text { loop }\end{array}$ \\
\hline 30 & Water Circulation Pump & WS-CP & 1 & $\begin{array}{l}15 \mathrm{MPa}, 50^{\circ} \mathrm{C}, 16.5 \\
\mathrm{LPM}(4.5 \mathrm{gpm}) ; 680 \\
\mathrm{~kg} / \mathrm{hr}\end{array}$ & $\begin{array}{l}\text { line pressure } 15 \mathrm{MPa} \text {, } \\
\text { loop delta- } \sim 20 \mathrm{kPa}\end{array}$ \\
\hline 31 & $\begin{array}{l}\mathrm{H}_{2} \mathrm{O}-\mathrm{H}_{2} \mathrm{O} \text { Recuperator / } \\
\text { Condenser }\end{array}$ & WS-RE & & $\begin{array}{l}15 \mathrm{MPa} \text {, heat duty: } \\
200 \mathrm{~kW}\end{array}$ & $\begin{array}{l}\text { heat recuperation, } \\
\text { allowing water pump } \\
\text { and flow meter to } \\
\text { operate at low Temp. }\end{array}$ \\
\hline
\end{tabular}


Table 6. (continued)

\begin{tabular}{|c|c|c|c|c|c|}
\hline 32 & Auxiliary Heater & WS-AH & 1 & $\begin{array}{l}\text { up to } 53 \mathrm{~kW} \text { (if SHX } \\
\text { is bypassed) }\end{array}$ & $\begin{array}{l}\text { primary heat addition } \\
\text { for independent } \\
\text { operation of water } \\
\text { loop (i.e., when SHX } \\
\text { is bypassed) }\end{array}$ \\
\hline 33 & $\begin{array}{l}\text { Steam/Water High Temp } \\
\text { Test Section }\end{array}$ & WS-HTS & 1 & $15 \mathrm{MPa}, 325^{\circ} \mathrm{C}$ & $\begin{array}{l}\text { flow, heat transfer, and } \\
\text { materials studies }\end{array}$ \\
\hline 34 & Chiller & WS-CH & 1 & $\begin{array}{l}53 \mathrm{~kW} \text { duty, } 15 \mathrm{MPa} \text {, } \\
100^{\circ} \mathrm{C}\end{array}$ & primary heat rejection \\
\hline 35 & $\begin{array}{l}\text { Cooling Water Pump (for } \\
\text { chiller) }\end{array}$ & WS-CHP & & $\begin{array}{l}5 \text { HP, } 4.2 \text { gpm, } 15.8 \\
\text { LPM }\end{array}$ & $\begin{array}{l}\text { prime mover for water } \\
\text { loop }\end{array}$ \\
\hline 36 & Chiller Cooling Water & WS-CHW & 1 & $0.2 \mathrm{MPa}, \Delta \mathrm{T}=50^{\circ} \mathrm{C}$ & \\
\hline 37 & $\begin{array}{l}\text { Steam/Water Chemistry } \\
\text { Control Section }\end{array}$ & WS-ChC & & $15 \mathrm{MPa}, 50^{\circ} \mathrm{C}$ & \\
\hline 38 & $\begin{array}{l}\text { Water Storage and } \\
\text { Deaeration Tank }\end{array}$ & WS-ST & & $\begin{array}{l}\mathrm{D}=0.76 \mathrm{~m}, \mathrm{H}=1.78 \mathrm{~m}, \\
\mathrm{~V}=810 \mathrm{~L}\end{array}$ & $\begin{array}{l}\text { storage of treated } \\
\text { water for entire loop }\end{array}$ \\
\hline 39 & Vaccum Pump & WS-VP & & $10^{-3}$ Torr & $\begin{array}{l}\text { deaeration of water } \\
\text { loop }\end{array}$ \\
\hline 40 & Valves & & & 2500 class & \\
\hline 40.1 & 3-way, High Temp Valve & WS-HTV & 6 & $15 \mathrm{MPa}, 350^{\circ} \mathrm{C}$ & \\
\hline 40.2 & 3-way, Low Temp Valve & WS-LTV & 8 & $15 \mathrm{MPa}, 75^{\circ} \mathrm{C}$ & \\
\hline 40.3 & Pressure Release Valve & WS-PRV & 2 & $15 \mathrm{MPa}, 50^{\circ} \mathrm{C}$ & \\
\hline 40.4 & Check Valve & WS-CV & 1 & TBD & \\
\hline 41 & Piping & & & $\begin{array}{l}15 \mathrm{MPa}, 350^{\circ} \mathrm{C}, \mathrm{NPS} \\
2, \text { schedule } 160\end{array}$ & SS 316 \\
\hline
\end{tabular}




\section{TECHNICAL CHALLENGES}

Development of advanced reactor technologies presents serious technical challenges. The operating conditions and materials compatibility issues noted in the previous sections are significant. Design, construction, and safe operation of the ARTIST facility at prototypical conditions will address many of the technical challenges that must be solved and demonstrated prior to deployment of advanced high-temperature reactor systems. In addition to the engineering challenges, the ARTIST facility is designed to address various research issues, discussed briefly in Section 2.

\subsection{Helium Loop}

The primary technical challenge associated with the helium loop is high operating temperature, up to $750^{\circ} \mathrm{C}$. Combined with an operating pressure of $7 \mathrm{MPa}$, high-temperature creep becomes a significant concern. One option mentioned in Section 3.5 is to use internally insulated piping such that the outer pipe pressure boundary is maintained at much lower temperature than the helium. This strategy has been proposed for the NGNP core outlet pipe [40] and it could be applied to the much smaller diameter piping of the ARTIST facility. This concept was discussed in some detail in reference [25]. The piping would include a light-gauge nickel-alloy (e.g., alloy 625) inner liner that prevents erosion and contamination of the insulation while providing a smooth flow boundary. The outer pressure boundary is thermally isolated from the flow liner by a high-performance insulation layer such as microporous insulation. For this type of system, the pressure boundary is at much lower temperature than the flow stream and the material can be a standard alloy such as stainless steel 304. Further technical and cost/benefit analysis of this strategy is required before a final selection is made.

An additional significant technical challenge for the He loop will be the sealing systems for hot high-pressure helium. Piping sections will be welded to the greatest extent possible to minimize leakage potential. Flanged pipe sections or components in the high-temperature portion of the loop will require special sealing strategies [25] such as the use of spring-energized metal O-ring seals. These systems are available from Helicoflex [41]. The use of valves in the high-temperature section will also be minimized.

\subsection{Intermediate Heat Transfer Loop}

The primary technical challenges associated with the liquid-salt intermediate heat transfer loop include design of the IHX and SHX, materials compatibility issues, salt chemistry control, and high melting point. These issues are discussed separately in the following subsections.

\subsubsection{IHX and SHX}

Advanced high-temperature reactor plant designs often include an IHTL with intermediate and secondary heat exchangers at either end to deliver thermal energy to the application while providing isolation of the primary reactor system. Consequently, a primary engineering and research objective for the ARTIST facility is demonstration and performance characterization of the intermediate and secondary heat exchangers at prototypical conditions, with large pressure differences across the heat exhangers. PCHEs have been identified as the baseline heat exchanger type for evaluation. The printed circuit heat exchanger (PCHE) is a relatively new concept that has been commercially manufactured by Heatric ${ }^{\mathrm{TM}}$ since 1985. PCHEs are robust heat exchangers that combine compactness, low pressure drop, high effectiveness, and the ability to operate at high pressure and with a very large pressure differential between hot and cold sides [42]. These heat exchangers are especially well suited to applications where compactness is important. The Heatric ${ }^{\mathrm{TM}}$ heat exchanger falls within the category of compact heat exchangers because of its high surface area density $\left(2,500 \mathrm{~m}^{2} / \mathrm{m}^{3}\right)$ [43]. PCHEs can be designed with very 
low pressure drop per unit heat transfer rate, resulting in a low ratio of fanning friction factor to Colburn $\mathrm{j}$ factor, $f / j_{H}$ [44], where $f$ is proportional to the pressure drop and is given by:

$$
f=\frac{\Delta P D_{h} \rho}{2 G^{2} L}
$$

and $j_{H}$ is proportional to the heat transfer coefficient:

$$
j_{H}=\frac{h}{G c_{P}} \operatorname{Pr}^{2 / 3}=\frac{N u}{R e \cdot \operatorname{Pr}^{1 / 3}}
$$

As the name implies, PCHEs are manufactured by the same technique used to produce printed circuit boards for electronic equipment. In the first step of the manufacturing process, fluid passages are photochemically etched into the metal plate. Normally, only one side of each plate is etched to produce channels. The etched plates are then joined by diffusion welding, resulting in extremely strong all-metal monolithic heat exchanger cores as shown in Figure 9. Plates for primary and intermediate fluids are stacked alternately and formed into a module. Modules may be used individually or joined with others to achieve the needed energy transfer capacity between fluids. The diffusion welding process produces grain growth across the weld joint, thereby producing a uniform metallurgical structure that is nearly as strong as the unwelded parent metal. Diffusion welding increases the expected lifetime of the heat exchanger such that it exceeds that of heat exchangers based on a brazed structure [45].

Although PCHEs have been identified for a number of years as excellent candidate heat exchangers for the IHX and SHX applications, technology demonstration has not yet been performed at prototypical conditions. The ARTIST facility will include three PCHEs. The first operates at IHX conditions, transferring heat from high-temperature, high-pressure helium to the liquid salt intermediate heat transfer loop. The second operates at SHX conditions, transferring heat from the low-pressure intermediate heat transfer loop to the high-pressure steam/water loop. The third PCHE operates as a He-He recuperator in the helium loop with essentially balanced high pressure on both sides, minimizing the possibility of leakage of primary fluid to the secondary side, but still potentially susceptible to creep. The recuperator can simulate the performance of a He-He IHX. The design details of each PCHE depend on the application specifications including working fluids, flow rates, heat duty, temperature, pressure, and allowable pressure drop. For the high operating temperature and pressure of the ARTIST helium loop, creep will be an important consideration. Material selection will be critical, especially with liquid fluoride salt on the secondary side. Probably the best overall material candidate material for the ARTIST IHX will be $800 \mathrm{H}$, which has been codified for use at temperatures up to $760^{\circ} \mathrm{C}$ and is also compatible with salt.
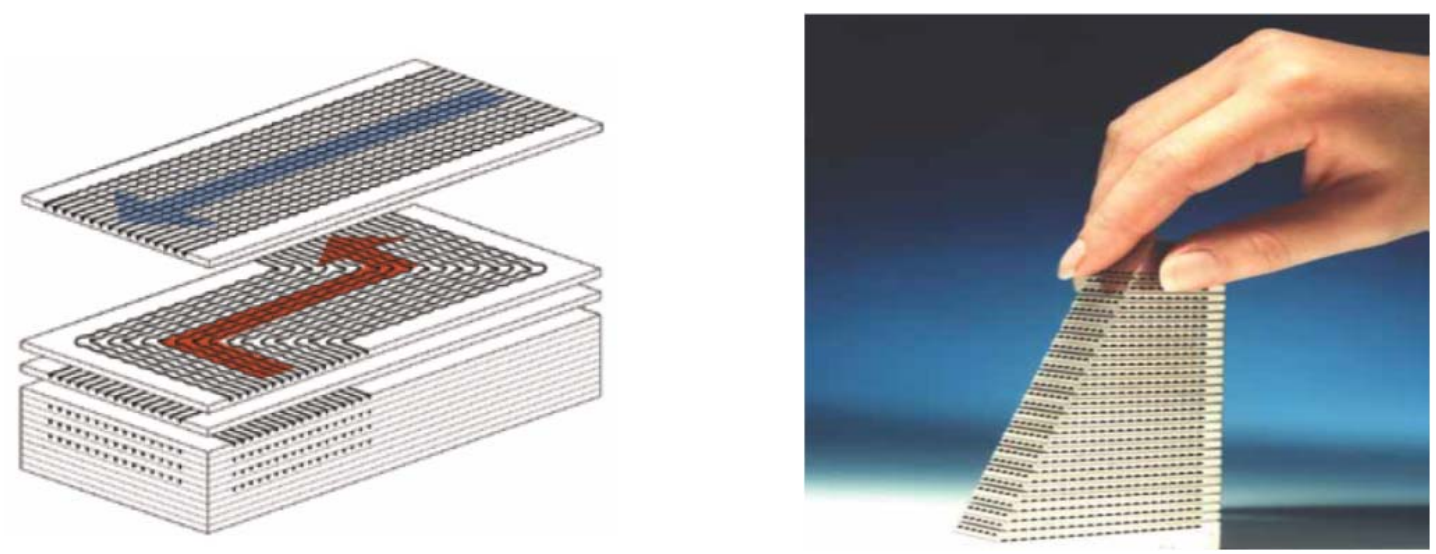

Figure 9. Diffusion bonded printed circuit heat exchangers. 
Another possibility would be $800 \mathrm{H}$ with a Hastelloy N liner for enhanced strength and better salt compatibility.

The flow channels in PCHEs are semi-circular, with a typical diameter around 1-2 mm. Each side of the heat exchanger includes multiple flow channels. INL has acquired a HEATRIC printed circuit heat exchanger (PCHE) designed as a recuperator for use in a supercritical power cycle demonstration. The heat exchanger is rated for a heat duty of $24 \mathrm{~kW}_{\text {th }}$. It is designed to operate at a pressure of 200 bar (2940 psia), an inlet temperature of $650^{\circ} \mathrm{C}$, with a supercritical $\mathrm{CO}_{2}$ flow rate of $120 \mathrm{~kg} / \mathrm{hr}$. The unit is fabricated from stainless steel $316 \mathrm{H}$. It has core dimensions of $116 \mathrm{~mm} \times 1196 \mathrm{~mm} \times 82 \mathrm{~mm}$. The heat exchanger was designed for use in a scaled supercritical $\mathrm{CO}_{2}$ power conversion system demonstration experiment at MIT. This heat exchanger may be incorporated into the ARTIST facility, possibly as a preliminary $\mathrm{He}-\mathrm{He}$ recuperator. The required total volume flow rate of helium for the ARTIST He loop is about a factor of 60 higher than the design volumetric flow rate of $\mathrm{CO} 2$ for the MIT recuperator. A photograph of the MIT CO2 recuperator is provided in Figure 10.

Flow channels in the PCHEs generally include a zigzag path in the flow direction. This etched flow pattern increases heat transfer surface area and heat transfer coefficients. The zigzag pattern precludes the attainment of traditional hydrodynamic and thermal fully developed conditions. However, a periodic fully developed regime can exist $[46,47]$. Channel flow geometry also affects the

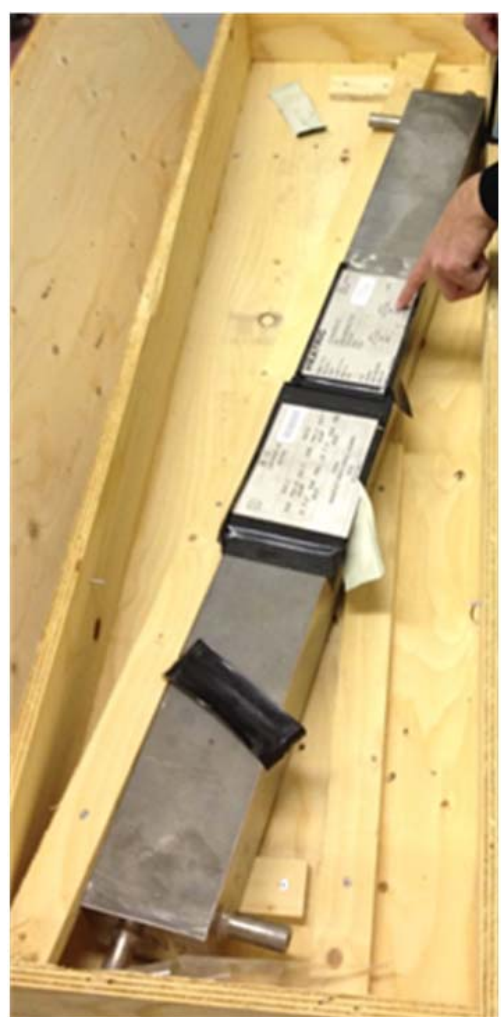

Figure 10. Heatric PCHE recuperator for $\mathrm{CO}_{2}$. pressure drop across the heat exchanger. The use of zigzag flow pattern increases the pressure drop. The magnitude of the pressure drop depends on the zigzag angle, the number of bends and their curvature [48]. Heat exchanger optimization is focused on minimization of the $f / j_{H}$ ratio for each application. Overall PCHE flow patterns include counterflow, crossflow, parallel flow, cross-counterflow, and serpentine counterflow [44].

\subsubsection{Liquid Salt Intermediate Heat Transfer Fluid}

Based on the required operating temperature and thermal characteristics, candidate salt coolants to be considered for liquid salt loop will be either fluoride or chloride salts. In terms of fluoride salts, potential choices include FLiBe, FLiNaK or $\mathrm{KF}-\mathrm{ZrF}_{4}$ and for chloride salts $\mathrm{KClMgCl}_{2}$ might also be considered at later stage. FLiBe is the most relevant choice for the primary loop coolant for fluoride-cooled reactors mainly because of its superior neutronic characteristics, but is ignored for the current loop, mainly because of safety concerns associated with beryllium.

Heat transfer fluids are selected based on various properties such as melting point, vapor pressure, density, thermal conductivity, heat capacity, viscosity, and coolant chemistry. In selecting a coolant, if a certain coolant shows superior properties, the decision can be very straightforward. However, generally each potential coolant exhibits good characteristics for some properties but poor for others. Therefore, it is very useful to develop figures of merit (FOMs) that can represent and quantify coolant thermal and chemical performance in the system of interest. The development of these FOMs is discussed in detail in reference [49]. A brief summary is provided here. Desirable characteristics for IHTL coolants include:

- High heat transfer performance

- Low pumping power 
- Low coolant volume

- Low quantity of structural materials

- Low heat loss

- Low temperature drop.

Corresponding to the six requirements listed above, six FOMs were developed in [49]. For example, consideration of appropriate correlations for heat transfer coefficient and pumping power for turbulent pipe flows yields the following expression for $F O M_{h t}$.

$$
F O M_{h t}=\frac{h}{h_{o}}=\left(\frac{k}{k_{o}}\right)^{0.6}\left(\frac{\rho}{\rho_{o}}\right)^{0.58}\left(\frac{C_{p}}{C_{p, o}}\right)^{0.4}\left(\frac{\mu}{\mu_{o}}\right)^{-0.47}
$$

In this equation, the denominator of each factor represents a reference fluid property and the denominator product can be written as $R_{o}$. The value of $F O M_{h t}$ quantifies the relative heat transfer performance of a candidate coolant evaluated at the same pumping power and flow geometry. Eq. (1) also reveals the sensitivity of this heat transfer performance criterion to the various fluid properties. The sensitivity to each property is given by the exponent of the corresponding factor. FOMs were also derived for the other coolant characteristics. A summary of the results is presented in Table 7. In the table, the equations for each FOM are provided in the first column and the sensitivities (exponents) associated with each fluid property are listed in the remaining columns. A comparison of FOM values for various candidate molten

Table 7. Summary of figures of merit for candidate coolant fluids.

\begin{tabular}{|c|c|c|c|c|c|}
\hline \multirow[b]{2}{*}{ Figure of Merit } & \multicolumn{5}{|c|}{ Sensitivity of Properties } \\
\hline & $S_{k}$ & $S_{\rho}$ & $S_{C p}$ & $S_{\mu}$ & $S_{P}$ \\
\hline $\begin{array}{l}\text { Heat transfer performance factor }\left(F O M_{h t}\right) \text { : } \\
\qquad F O M_{h t}=\frac{(k)^{0.6} \cdot(\rho)^{0.58} \cdot\left(C_{p}\right)^{0.4} \cdot(\mu)^{-0.47}}{R_{h t, 0}}\end{array}$ & 0.6 & 0.58 & 0.4 & -0.47 & 0.0 \\
\hline $\begin{array}{l}\text { Pumping factor }\left(F O M_{p}\right) \text { : } \\
F O M_{p}=\frac{\rho^{-2} \cdot C_{P}^{-2.8} \cdot \mu^{0.2}}{R_{p, 0}}\end{array}$ & 0.0 & -2 & -2.8 & 0.2 & 0.0 \\
\hline $\begin{array}{l}\text { Coolant volume factor }\left(F O M_{c v}\right) \text { : } \\
F O M_{c v}=\frac{(\rho)^{-0.84} \cdot\left(C_{p}\right)^{-1.16} \cdot(\mu)^{0.1}}{R_{c v, 0}}\end{array}$ & 0.0 & -0.84 & -1.16 & 0.1 & 0.0 \\
\hline $\begin{array}{l}\text { Material Volume factor }\left(F O M_{c c v}\right) \text { : } \\
F O M_{c c v}=\frac{(P) \cdot(\rho)^{-0.84} \cdot\left(C_{p}\right)^{-1.16} \cdot(\mu)^{0.1}}{R_{c c v, 0}}\end{array}$ & 0.0 & -0.84 & -1.16 & 0.1 & 1.0 \\
\hline $\begin{array}{c}\text { Heat loss factor }\left(F O M_{h l}\right): \\
F O M_{h l}=\frac{(k)^{0.6} \cdot(\rho)^{0.34} \cdot\left(C_{p}\right)^{0.06} \cdot(\mu)^{-0.44}}{R_{h l, 0}}\end{array}$ & 0.6 & 0.34 & 0.06 & -0.44 & 0.0 \\
\hline $\begin{array}{l}\text { Temperature drop factor }\left(F O M_{d t}\right) \\
F O M_{d t}=\frac{(k)^{0.6} \cdot(\rho)^{0.34} \cdot\left(C_{p}\right)^{0.06} \cdot(\mu)^{-0.44}}{R_{d t, 0}}\end{array}$ & 0.6 & 0.34 & 0.06 & -0.44 & 0.0 \\
\hline
\end{tabular}


Table 8. Comparisons of FOM values for various coolant salt candidates.

\begin{tabular}{|c|c|c|c|c|c|c|c|c|c|c|c|c|}
\hline Coolant & $\begin{array}{c}\text { Melting } \\
\text { Point } \\
\left({ }^{\circ} \mathrm{C}\right) \\
\end{array}$ & $\begin{array}{c}\mathrm{k} \\
(\mathrm{W} / \mathrm{m} \mathrm{K}) \\
\end{array}$ & $\begin{array}{c}\mathrm{P} \\
(\mathrm{kg} / \mathrm{m} 3) \\
\end{array}$ & $\begin{array}{c}\mathrm{Cp} \\
(\mathrm{J} / \mathrm{kg} \mathrm{K}) \\
\end{array}$ & $\begin{array}{c}\mu \\
(\mathrm{Pa} \mathrm{s}) \\
\end{array}$ & $\begin{array}{c}\mathrm{P} \\
(\mathrm{atm}) \\
\end{array}$ & $\mathrm{FOM}_{\mathrm{ht}}$ & $\mathrm{FOM}_{\mathrm{p}}$ & $\mathrm{FOM}_{\mathrm{cv}}$ & $\mathrm{FOM}_{\mathrm{ccv}}$ & $\mathrm{FOM}_{\mathrm{hl}}$ & $\mathrm{FOM}_{\mathrm{dt}}$ \\
\hline Water $\left(25^{\circ} \mathrm{C}\right)$ & 0 & 0.61 & 997.05 & 4181 & 0.00089 & 1 & 1.00 & 1.00 & 1.00 & 1.00 & 1.00 & 1.00 \\
\hline LiF-NaF-KF & 454 & 0.92 & 2020 & 1886 & 0.0029 & 1 & 0.80 & 2.87 & 1.57 & 1.57 & 0.92 & 0.92 \\
\hline $\mathrm{NaF}-\mathrm{ZrF}_{4}$ & 500 & 0.49 & 3140 & 1173 & 0.0051 & 1 & 0.45 & 5.02 & 1.98 & 1.98 & 0.56 & 0.56 \\
\hline $\mathrm{KF}-\mathrm{ZrF} \mathrm{F}_{4}$ & 390 & 0.45 & 2800 & 1046 & 0.0051 & 1 & 0.38 & 8.69 & 2.49 & 2.49 & 0.51 & 0.51 \\
\hline $\begin{array}{l}\mathrm{LiF}-\mathrm{NaF}- \\
\mathrm{ZrF}_{4}\end{array}$ & 436 & 0.53 & 2920 & 1233 & 0.0069 & 1 & 0.40 & 5.36 & 2.05 & 2.05 & 0.50 & 0.50 \\
\hline $\mathrm{LiCl}-\mathrm{KCl}$ & 355 & 0.42 & 1520 & 1198 & 0.00115 & 1 & 0.55 & 14.99 & 3.07 & 3.07 & 0.76 & 0.76 \\
\hline $\mathrm{LiCl}-\mathrm{RbCl}$ & 313 & 0.36 & 1880 & 890 & 0.0013 & 1 & 0.47 & 23.03 & 3.66 & 3.66 & 0.70 & 0.70 \\
\hline $\mathrm{NaCl}-\mathrm{MgCl}_{2}$ & 445 & 0.5 & 1680 & 1096 & 0.00136 & 1 & 0.58 & 16.26 & 3.18 & 3.18 & 0.81 & 0.81 \\
\hline $\mathrm{KCl}-\mathrm{MgCl}_{2}$ & 426 & 0.4 & 1660 & 1160 & 0.0014 & 1 & 0.50 & 14.30 & 3.02 & 3.02 & 0.70 & 0.70 \\
\hline $\mathrm{NaF}_{-\mathrm{NaBF}}$ & 385 & 0.4 & 1750 & 1507 & 0.0009 & 1 & 0.71 & 5.66 & 2.04 & 2.04 & 0.88 & 0.88 \\
\hline $\mathrm{KF}-\mathrm{KBF}_{4}$ & 460 & 0.38 & 1700 & 1305 & 0.0009 & 1 & 0.64 & 8.98 & 2.47 & 2.47 & 0.84 & 0.84 \\
\hline $\mathrm{RbF}-\mathrm{RbF}_{4}$ & 442 & 0.28 & 2210 & 909 & 0.0009 & 1 & 0.54 & 14.61 & 3.01 & 3.01 & 0.75 & 0.75 \\
\hline
\end{tabular}

salt coolants is presented in Table 8. A high value of $\mathrm{FOM}_{\mathrm{ht}}$ is preferred, whereas for all of the other FOMs, a low value is preferred. The best overall candidate based on these FOM value is LiF-NaF-KF (FLiNaK). However, $\mathrm{KF}_{-} \mathrm{ZrF}_{4}(58-42)$ is a good candidate in most categories as an alternative and it has one of the lowest melting points, which reduces some of the design challenges for the test loop. Therefore $\mathrm{KF}-\mathrm{ZrF}_{4}$ has been selected as our baseline salt. One objective of the project will be to expand the data base for the thermophysical properties of this particular salt. This salt has also been selected by ORNL as the intermediate loop coolant for the Small Modular Advanced High-Temperature Reactor (SmAHTR) [50], primarily based on its low melting point. The SmAHTR is a small fluoride-salt-cooled high-temperature reactor concept designed to support coupled industrial processes such as hydrogen production. The primary reactor coolant for this concept is FLiBe.

\subsubsection{Salt Chemistry Control}

Impurities in liquid salt mixtures play a critical role in corrosion of structural materials. These impurities primarily include several metal oxides resulting from the absorbed moisture during the production process of salt mixture. Other sources include the starting material, but this source can be controlled by purchasing high purity salts from vendors who can document careful quality control. In general, these impurities lead to chromium depletion from the surface of structural materials in contact with fluoride salts. The products formed by the chromium depletion reaction may accelerate further chromium depletion. Thus, continuous elimination of impurities, or routine chemistry control during operation, is of great importance. A salt chemistry control section has been included in the liquid salt loop (see Figure 2) for this purpose. In this section, removal of oxide, sulfur and structural-metal impurities will be discussed.

The treatment used in the Molten-Salt Reactor Experiment (MSRE) program at Oak Ridge National Laboratory (ORNL) to remove oxides was to sparge the molten fluoride melt with anhydrous hydrogen fluoride $[51,52]$ according to the equilibrium reaction:

$$
\mathrm{O}^{2-}+2 \mathrm{HF} \rightleftharpoons 2 \mathrm{~F}^{-}+\mathrm{H}_{2} \mathrm{O}
$$

The addition of excess HF causes this reaction to shift to the right. Using this strategy, oxides are removed continuously from the process as water vapor. This method is confirmed to be highly effective at 
relatively low temperature. The treatment with HF is recommended to be continued beyond reaction completion to ensure removal of inadvertent contamination [51].

Hydroxides are also removed by HF treatment according to the equilibrium reaction:

$$
\mathrm{OH}^{-}+\mathrm{HF} \rightleftharpoons \mathrm{F}^{-}+\mathrm{H}_{2} \mathrm{O}
$$

It is noteworthy that HF imposes a significant corrosive threat to structural materials such as the treatment vessel. A solution was to utilize alternate gas treatment with $\mathrm{HF}$ and $\mathrm{H}_{2}$. The hydrofluoric acid reacted with oxides and hydroxides, fluorinating them while simultaneously releasing water vapor. Metal impurities such as iron and chromium were reduced by hydrogen gas and filtered out of the salt. By removing these impurities, the corrosion of reactor components was minimized. However this treatment, which could to some extent prevent serious corrosion, had drawbacks. In the gas phase of the treatment vessel, for example, an impervious layer of structural-material fluorides will be formed during treatment by the reaction:

$$
M^{o}+2 H F \rightleftharpoons M F_{2}+H_{2}
$$

[51,52]. In the liquid phase, layers formed on the surfaces contacting molten fluoride salts may be renewed by dissolution of the layers. The alternating oxidation and reduction of structural-material during alternate gas treatment may eventually cause failure of vessel walls.

Another solution was to use $\mathrm{HF}$ and $\mathrm{H}_{2}$ simultaneously, which had been tested in the Engineering Test Loop Facility in the MSRE. This gas treatment was effective typically at $\mathrm{H}_{2}$ concentration of $1 / 10$ mole fraction admixed with $\mathrm{HF}$ [51]. It also prohibited the corrosiveness of $\mathrm{HF}-\mathrm{H}_{2} \mathrm{O}$ effluent gas mixture. Tests indicated that only minor corrosion occurred [51].

Gas treatment with HF was also used to remove sulfur in the MSRE. Sulfur is usually present in the form of sulfate, which needs to be first reduced to sulfide ion and then be volatilized as $\mathrm{H}_{2} \mathrm{~S}$ by reaction with $\mathrm{HF}$. Alternate gas treatment with $\mathrm{HF}-\mathrm{H}_{2}$ was reasonably effective, but increased treatment times were required because of discontinuous sulfide removal that affects quality control. Simultaneous gas treatment could continuously remove sulfate but removal rate is relatively low. Another concern is the rapid effective reduction of sulfate because at high temperature the products of thermal decomposition of sulfate may corrode nickel or copper salt container. Additional metallic reducing agents were used such as beryllium [51]. Removal of structural-metal impurities can ensure no initial rapid chromium depletion. Thus chemistry control on these impurities is especially important. Generally, chromium depletion is induced by $\mathrm{HF}, \mathrm{NiF}_{2}, \mathrm{FeF}_{2}$ and $\mathrm{FeF}_{3}$, etc. These metal fluorides are possibly generated by the structural metal dissolved in the fluoride salts. These impurities can then in turn extract chromium from structural metals and become dissolved in fluoride salts again, for instance, shown by the reaction

$$
\mathrm{Cr}+\mathrm{FeF}_{2} \rightleftharpoons \mathrm{CrF}_{2}+\mathrm{Fe}
$$

In the MSRE, hydrogen was used as a final gas sparge treatment to remove these impurities [shown in Eq. (3)]. This treatment, similarly, was later replaced by $\mathrm{HF}-\mathrm{H}_{2}$ mixture gas. Nickel fluoride was removed most readily, followed by iron fluoride and chromium fluoride. But the concentration of chromium was acceptable most of the time. A higher hydrogen flow rate leads to better removal of impurities. However, a hydrogen flow rate (10 liters/min) caused frequent entrainment of salt in the gas effluent lines [51].

A new chemical purification process for fluoride salts that makes use of a less dangerous cleaning gas, nitrogen trifluoride $\left(\mathrm{NF}_{3}\right)$, has been evaluated as an alternative to the $\mathrm{HF} / \mathrm{H}_{2}$ system $[53,54]$.

Compared to $\mathrm{HF}, \mathrm{NF}_{3}$ is only mildly toxic, noncorrosive, and nonreactive at room temperature. It has been predicted to be an effective purification agent for fluoride coolant salts [53]. Nitrogen trifluoride has been demonstrated as effective at removing oxide, hydroxide, and water contamination from fluoride salts during melt processing of fluoride glass. Demonstration of chemistry control methodologies along with 
potential reduction in corrosion is essential for the use of a fluoride salt as a reactor coolant for the FHR or as an intermediate heat transfer fluid.

\subsection{Steam/Water Loop}

The primary technical challenges associated with the design and deployment of the steam/water loop are high pressure and the support of both single- and two-phase flow. Nominal loop operating conditions will be designed to simulate PWR conditions, with a loop pressure of $15 \mathrm{MPa}$ and a maximum temperature of $325-340^{\circ} \mathrm{C}$. The test section will be designed to accommodate PWR core rod bundle configurations with electrically heated simulated fuel rods for cladding materials studies. Testing of accident-tolerant fuels based on various strategies including coatings, overbraiding, etc. will be supported. The steam/water loop will be heated via heat transfer in the SHX. The SHX will operate with low-pressure salt on side A and high-pressure water on side B. The SHX must maintain full integrity under challenging operating conditions. Demonstration of SHX operation and performance will be a major objective of the research. Pressure in the loop will be maintained by means of a piston accumulator, with pressure-regulated $\mathrm{N}_{2}$ on the gas side.

\subsection{Test Matrix Development}

The objective of this project is to support the design, fabrication, assembly, and initial operation of a high-temperature flow and heat transfer loop and thermal energy storage system, with a focus on advanced reactor applications. This work will advance the state of the art and technology readiness level of high-temperature heat transfer components (HTCs) such as IHXs for nuclear applications while establishing INL as a center of excellence for the development and certification of this technology. The thermal energy storage capability will support research and demonstration activities related to process heat delivery for a variety of hybrid energy systems and grid stabilization strategies. For the HTCs, demonstration at prototypical conditions as well as accurate determination of the heat transfer and pressure drop performance is essential for correct characterization of the thermal-hydraulic phenomena for identifying the gaps and for validation of models.

Following construction of each loop, shakedown testing will be conducted. This testing will be designed to verify the performance of all system components, seals, instrumentation, instrument control software, and data acquisition systems. Shakedown tests will initially be performed at low pressure and temperature, eventually increasing to full design conditions. Shakedown testing will be followed by loop performance qualification testing. During this stage of testing, the design performance of each component will be verified. For example, the pressure drop characteristics of the heat exchangers will be measured across a range of flow rates, temperatures, and pressures. The heat transfer performance of the heat exchangers will also be measured and compared to design specifications. Loop pressure drop will be measured and the performance of the circulators and pumps will be verified. Common testing needs for all three loops are listed below, followed by individual loop test objectives.

\section{Common Testing Needs for He, Salt, and Water Loop}

- Show compatibility with structural material and development of material property database at the required temperature and pressure

- Measure heat transfer rates and pressure drops across the test section, heat transfer components, and entire loop

- Develop new maintenance and inspection techniques, in-service examination, and monitoring

- Study corrosion effects at high temperatures and with varying concentration of contaminants 
- Evaluate heat exchanger joining/bonding (diffusion bonding) performance and degradation mechanisms; verify material properties database (at the design temperature and pressure)

- Test high temp components (such as valves and pumps) to demonstrate performance and compatibility

- Investigate nondestructive methods for detecting cracks in components without physical contacts (e.g., laser methods)

- Develop and test advanced instrumentation at prototypical conditions

- Develop a system design that allows measurements at natural circulation conditions for possible evaluation of passive safety systems for advanced reactor concepts.

\section{Individual Loop Test Objectives}

1. Helium Loop $(\mathrm{P}=7 \mathrm{MPa}, \mathrm{T}=750 \mathrm{deg} \mathrm{C})$

1.1 High-temperature creep behavior of IHX material

1.2 Oxidation effects associated with air or water ingress

1.3 Leakage issues

1.4 Flow and stability concerns

1.4.1 Flow distribution in prototypical core geometries, bypass flow

1.4.2 Viscosity effect with increase in temperature (leading to increase in flow resistance)

1.4.3 Laminar instability (mainly encountered during core startup when flow is low): this instability has been associated with the negative values of the rate of change of pressure drop with flow rate $\left(\frac{\partial \mathrm{P}}{\partial \dot{\mathrm{m}}}\right)<0$; that is decrease in mass flow through the channel can yield an increase in pressure drop, as explained by Melese and Katz [12].

1.5 Heat Transfer Issues

\subsubsection{Core heat transfer}

1.5.2 Turbulent heat transfer deterioration

1.5.3 Correlation validation

1.6 High-temperature component performance (valves, blower/circulator)

1.7 Heat exchanger (IHX) performance

1.8 High temperature instrumentation performance verification

1.9 Evaluation of joining mechanisms

1.10 Experimental data for $\mathrm{V} \& \mathrm{~V}$

2. $\quad$ Liquid Salt Loop $(\mathrm{P}=0.2 \mathrm{MPa}, \mathrm{T} \sim 400-500 \mathrm{deg} \mathrm{C})$

2.1 Corrosion issues and materials compatibility

\subsubsection{Metallic components}

2.1.2 Ceramic and composite materials

2.2 High-temperature thermal energy storage system characterization

2.3 Fundamental heat transfer issues

2.3.1 High Prandtl numbers

2.3.2 Low Reynolds numbers 


\subsection{Instrumentation assessment and development}

2.5 High-temperature components (valves, pump)

2.6 Heat exchanger

2.6.1 Joining mechanisms

2.6.2 Heat transfer behavior and correlation validation

2.7 Experimental data for $\mathrm{V} \& \mathrm{~V}$

3. Water/Steam Loop (testing at PWR conditions, $\mathrm{P}=15 \mathrm{MPa}, \mathrm{T}=50-350^{\circ} \mathrm{C}$ )

3.1 Evaluation of accident-tolerant fuel cladding

3.1.1 $\mathrm{SiC}$ or $\mathrm{Fe}-\mathrm{Cr}-\mathrm{Al}$

3.1.2 Corrosion and CRUD formation

3.2 Power cycle (Rankine) high-temperature material corrosion issues

3.3 Leakage issues in the heat exchanger/steam generator

3.4 Flow-induced vibration in rod bundles

3.5 Experimental data for $\mathrm{V} \& \mathrm{~V}$

\section{SUMMARY AND CONCLUSIONS}

A conceptual design for a new high-temperature, multi-fluid multi-loop test facility has been presented in this report. Based on its relevance to advanced reactor systems, the new facility has been named the Advanced Reactor Technology Integral System Test (ARTIST) facility. This facility will support thermal hydraulic, materials, and thermal energy storage research for nuclear and nuclear-hybrid applications. Three flow loops will be included: a high-temperature helium loop, a liquid salt loop, and a hot water/steam loop. The three loops will be thermally coupled through an intermediate heat exchanger (IHX) and a secondary heat exchanger (SHX). The salt loop is representative of an advanced reactor system intermediate heat transfer loop. Advanced reactor systems often include an intermediate heat transfer loop (IHTL) with heat exchangers at either end to deliver thermal energy to the application while providing isolation of the primary reactor system. Liquid salts have been identified as excellent candidate heat transport fluids for intermediate loops, supporting several types of advanced high temperature reactors. Liquid salts have also been proposed for use as a primary coolant for the Advanced High Temperature Reactor (AHTR) and the Fluoride salt-cooled high temperature reactor (FHR).

Engineering research topics to be addressed with this facility include the characterization and performance evaluation of candidate compact heat exchangers such as printed circuit heat exchangers (PCHEs) at prototypical operating conditions, flow and heat transfer issues related to core thermal hydraulics in advanced helium-cooled and salt-cooled reactors, and evaluation of corrosion behavior of new cladding materials and accident-tolerant fuels for LWRs at prototypical conditions. Research performed in this test facility will advance the state of the art and technology readiness level of high temperature intermediate heat exchangers (IHXs) for nuclear applications while establishing INL as a center of excellence for the development and certification of this technology. The thermal energy storage capability will support research and demonstration activities related to process heat delivery for a variety of hybrid energy systems and grid stabilization strategies.

Fundamental research topics will also be addressed with this facility. Each loop will include a high-temperature test section for this purpose. Research topics that may be studied in the high temperature helium test section include flow distribution, bypass flow, and heat transfer in prototypical prismatic core configurations under forced and natural circulation conditions, parallel flow laminar instability during 
pressurized cooldown, and turbulent heat transfer deterioration. Oxidation effects associated with water or air ingress could also be examined. The high temperature test section in the liquid salt loop can be used for examination of materials issues, thermal stresses, and high-Prandtl-number heat transfer issues. The high temperature test section in the steam/water loop will be used primarily for prototypic evaluation of new cladding materials and accident-tolerant fuels. It will be designed to characterize the thermal, chemical, and structural properties of candidate advanced fuel cladding materials and designs under a variety of simulated flow and internal heating conditions to mimic operational reactor conditions prior to in-reactor testing. The liquid salt loop will also include a thermal energy storage (TES) system for support of thermal integration studies. The TES system will be based on freezing and melting of the salt acting as a high-temperature phase change material (PCM).

In the process of completing this conceptual design, commercial hardware was identified for all noncustom components. Some of these components will be operated very close to their performance limits in terms of pressure, temperature, and materials compatibility. The demanding operating requirements for this loop will be a major factor in determining the cost of all the components and the total facility cost.

The experiments carried out in the facility are expected to advance the Technology Readiness Level of important components such as PCHEs, while also producing in significant knowledge of heat-transfer mechanisms and material compatibility and component testing at prototypical conditions. The database will also be used to evaluate existing performance models and correlations in predicting heat transfer coefficients. New models and/or correlations will be developed as needed. The scope of the heat transfer experiments will primarily be collection of data about heat transfer coefficient and pressure drop in the respective salt, Helium and $\mathrm{H}_{2} \mathrm{O}$ loops.

Components and subsystems will have to be qualified in a relevant environment for use in advanced reactor concepts. For example, Alloy $800 \mathrm{H}$ which is being considered as one of the potential structural material for the advanced reactors and is ASME codified up to $760^{\circ} \mathrm{C}$, nevertheless additional data is still needed in the relevant environment. The proposed loop will not only demonstrate the developed technology, but will also be a test bench/testing facility for the evolution and further development of advanced reactor component technology towards an extended scope of applications with higher performance capabilities. For allowing such evolution, tests of advanced components and technologies will have to be performed and heat transport in small scale facilities will be of great help for screening different technological options and design solutions, for selecting and for validating the most relevant concepts:

- Intermediate and Process Heat Exchanger for transferring heat to applications that require temperatures above $600^{\circ} \mathrm{C}$

- Compact heat exchanger performance: possible impact of channel geometry and coolant on the heat transfer coefficient can be assessed along with potential fouling issues and its effect on overall heat transfer

- Advanced materials that allow higher system performance (in particular in terms of operating temperature)

- Advanced cladding materials, such as Fe-Cr-Al, being proposed for LWR's under accident tolerant fuel initiative

- Corrosion which could be a show stopper for few of the advanced reactor concepts; this can be assessed as a function of impurity content with the help of the chemistry control loop

- Advanced materials such as ceramics for heat exchanger and metal-ceramic joining mechanism

- System components such as: circulators, recuperators, pumps, check valves, etc.

- Structural materials for salt storage mainly for energy storage application. 
Apart from component testing, the proposed multi-purpose test loop can provide representative operating conditions to support code qualification with relevant experimental data. The proposed facility could be used to acquire thermal-fluid experimental data from steady-state and transient operation of the loop for enriching the experimental database for qualification of system transient analysis codes.

\section{FUTURE WORK/PATH FORWARD}

Following completion of the conceptual design (presented in this report), near-term continuation tasks include:

- Finalize the technical and functional requirements for the ARTIST facility.

- Develop detailed performance specifications for each component, recognizing cost and feasibility constraints, including consideration of the technical challenges detailed in this report.

- Consult with vendors to determine the best choice of materials, geometrical configuration, and performance characteristics, achievable within a reasonable budget. The operating conditions (temperature, pressure, pressure drop, heat duty or heat loss, fluid, materials compatibility) of each component must be carefully considered as part of this process.

- Develop cost estimates for each loop

- Thermal-hydraulic, chemical and structural phenomena that could be studied in the ARTIST facility will be identified based on Phenomena Identification and Ranking Tables (PIRTs) for AHTRs to guide development of an experimental test matrix.

- Identify initial subsystem configuration (e.g., helium loop only); procure hardware for initial configuration as budget permits; long-lead-time components should be purchased first.

- Perform uncertainty analysis for quantification of data uncertainty and to guide specification of instrumentation.

- Perform shakedown testing with initial facility configuration. 


\section{REFERENCES}

1. Williams, D. F., Clarno, K. T., and Toth, L. M., "Assessment of Candidate Liquid-Salt Coolants for the Advanced High-Temperature Reactor (AHTR)," ORNL/TM-2006/12, Oak Ridge National Laboratory, 2006.

2. Williams, D. F., and Clarno, K. T., "Evaluation of Salt Coolants for Reactor Applications," Nuclear Technology, Vol. 163, pp. $330-343,2008$.

3. Sohal, M. S., Ebner, M. A., Sabharwall, P., and Sharpe, P., "Engineering Database of Liquid Salt Thermophysical and Thermochemical Properties," INL/EXT-10-18297, March, 2010.

4. Benes, O., Cabet, C., Delpech, S., Hosnedl, P., Ignatiev, V., Konings, R., Lecarpentier, D., Matal, O., Merle-Lucotte, E., Renault, C., and Uhlir, J., "Assessment of Liquid Salts for Innovative Applications," ALISIA Deliverable (D-50), European Commission, Euratom Research and Training Programme on Nuclear Energy, February 2009.

5. Forsberg, C. W., "The Advanced High-Temperature Reactor: High-Temperature Fuel, Liquid Salt Coolant, Liquid-Metal-Reactor Plant," Prog. Nuc. Energy, Vol. 47, pp. 32 -43, 2005.

6. Scarlat, R. O., and Peterson, P. F., "The Current Status of Fluoride Salt-Cooled High- Temperature Reactor (FHR) Technology and Its Overlap with HIF Target Chamber Concepts," Nuc. Inst and Methods in Physics Res. A., 2013.

7. Zweibaum, N., Cao, G., Cisneros, A. T., Kelleher, B., Laufer, M. R., Scarlat, R. O., Seifried, J. E., Anderson, M. H., Forsberg, C. W., Greenspan, E., Hu, L. W., Peterson, P. F., Sridharan. K., "Phenomenology, Methods, and Experimental Program for Fluoride-Salt-Cooled High Temperature Reactors," Progress in Nuclear Energy, in press, 2014.

8. Urquiza, E., Lee, K., Peterson, P. F., and Grief, R., "Multiscale Transient Thermal, Hydraulic, and Mechanical Analysis Methodology of a Printed Circuit Heat Exchanger Using an Effective Porous Media Approach," J. Thermal Science and Engineering Applications, Vol. 5, pp. 041011-1:8, December 2013.

9. Schultz, R. S., et al., "Next Generation Nuclear Plant Methods Technical Program Plan," INL/EXT-06-11804, January 2007.

10. Tung, Y., Johnson, R. W., Ferng, Y., and Chieng, C., "Bypass Flow Computations on the LOFA Transient in a VHTR," Applied Thermal Engineering, Vol. 62, pp. 415-423, 2014.

11. Reshotko, E., "Analysis of Laminar Instability Problem in Gas-cooled Nuclear Reactor passages," AIAA Journal, Vol. 5, pp. 1606-1615, 1967.

12. Melese, G., and Katz, R., Thermal and Flow Design of Helium-Cooled Reactors, ANS, ISBN 978-0894480270, 1984.

13. McEligot, D. M., and Jackson, J. D., "Deterioration Criteria for Convective Heat Transfer in Gas Flow Through Non-Circular Ducts," Nuc. Eng. and Design, Vol. 232, pp. 327-333, 2004.

14. Lee, J. I., Hehzlar, P., Saha, P., and Kazimi, M. S., "Studies of the Deteriorated Turbulent Heat Transfer Regime for the Gas-Cooled Fast Reactor Decay Heat Removal System," Nuc. Eng. and Design, Vol. 237, pp. 1033-1045, 2007.

15. Chapin, D., Kiffer, S., and Nestell, J., "The Very High Temperature Reactor: A Technical Summary," MPR Associates, June 2004.

16. Hoshi, A., Mills, D. R., Bittar, A., and Saitoh, T. S., "Screening of High Melting Point Phase Change Materials (PCM) in Solar Thermal Concentration Technology," Solar Energy, Vol. 79, pp. 332-339, 2005. 
17. Gomez, J. C., "High-Temperature Phase Change Materials (PCM) Candidates for Thermal Energy Storage Applications,” NREL Report NREL/TP-5500-51446, 2011.

18. Bojarsky, E., Deckers, H., Lehning, H., Reiser, P. H., and Schmidt, L., "THIBO Experiments Thermohydraulically Induced Fuel Pin Oscillations in Na-Cooled Reactors," Nuclear Engineering and Design, Vol. 130, pp. 21-26, 1991.

19. Yoder, G. L., Aaron, A., Cunningham, B., Fugate, D., Holcomb, D., Kisner, R., Peretz, F., Robb, K., Wilgen, J., and Wilson, D., "An Experimental Test Facility to Support Development of the Fluoride-Salt-Cooled High-Temperature Reactor, Annals of Nuclear Energy, Vol. 64, pp. 511-517, 2014.

20. Gill, D. D., Kolg, W. J., Briggs, R. J., and Pettit, K. P., "Customer Interface Document for the Molten Salt Test Loop (MSTL) System, Sandia Report SAND2012-1905, March 2012.

21. Jeong, H-S., Hwang, I-S., and Bang, K-H., “A Study on the Thermal-Hydraulic Characteristics of Molten Salt in Minichannels of an Intermediate Heat Exchanger for a Very High Temperature Reactor (VHTR),” KSME-B.2010.34.12.1093, ISSN 1226-4881, pp. 1093-1099, 2010.

22. Sabharwall, P., Ebner, M., Sohal, M., Sharpe, P., Anderson, M., Sridharan, K., Ambrosek, J., Olson, L., and Brooks, P., "Molten Salts for High Temperature Reactors: University of Wisconsin Molten Salt Corrosion and Flow Loop Experiments - Issues Identified and Path Forward," INL/EXT-10-18090, 2010.

23. Toda, S., Chiba, S. Yuki, K., Omae, M., and Sagara, A., "Experimental Research on Molten Salt Thermofluid Technology Using a High-Temperature Molten Salt Loop Applied for a Fusion Reactor Flibe Blanket," Fusion Engineering and Design, Vol. 63-64, pp. 405-409, 2002.

24. Sun, Xiaodong, personal communication, 2014.

25. Kesseli, J. B., Wolf, T. L., Hodous, F. W., Nash, J. S., Child, M. S., Cherry, R. S., Williamson, R. L., Reed, T. R. and Palmer, A. J., "Conceptual Design for a High-Temperature Gas Loop Test Facility," INL/EXT-06-11648, August 2006.

26. Mylavarapu, S. K., Sun, X., Glosup, R. E., Christensen, R. N., and Patterson, M. W., "Thermal Hydraulic Performance Testing of Printed Circuit Heat Exchangers in a High-Temperature Helium Test Facility," Applied Thermal Engineering, Vol. 65, pp. 605-614, 2014.

27. Chromalox MI Mineral Insulated Cable brochure.

28. Velan brochure, "Cast Steel Valves; Gate, Globe, and Check," Velan Inc., 2013.

29. Scarlat, R. O., Laufer, M., Zweibaum, N., Bickel, J., "Design and Proof testing of the AHTR Compact Integral Effects Test (CIET) Facility,” Final Report, UC Berkeley, October 30, 2012.

30. Nagle brochure, "Molten Salt Pumps," Nagle Pumps, Inc., 2013.

31. Patterson, M., W., "Instrumentation Strategy for Test Loops and Facilities for the Heat Transport Portion of NGNP," INL PlanPLN-3, June 2010.

32. "Challenges Related to the Use of Liquid Metal and Molten Salt Coolants in Advanced Reactors," IAEA-TECDOC-1696, 2013.

33. GE Measurement and Control Brochure, "Panaflow HT Panametrics Ultrasonic SIL Flow Meter for Liquids."

34. Gefran Brochure, "Melt Pressure Transducers and Transmitters."

35. Ritchie, J. A., Pressure Measurement Instrumentation in a High Temperature Molten Salt Test Loop, MS Thesis, U. of Tennessee, 2010. 
36. "PWR Primary Water Chemistry Guidelines,” EPRI Technical Report, TR-105714-V1R4, March 1999.

37. Terachi, T., Yamada, T., Miyamotot, T., Arioka, K., and Fuku, K., "Corrosion Behavior of Stainless Steels in Simulated PWR Primary Water - Effect of Chromium Content in Alloys and Dissolved Hydrogen,” J. Nuclear Science and Technology, Vol. 45, No. 10, pp. 975-984, 2008.

38. ASTM Standard C1676, 2008, "Standard Specification for Microporous Thermal Insulation", ASTM International, West Conshohocken, PA, 2008, www.astm.org.

39. Sun, X., Kim, I. and Zhang, X., "Development of an INL Capability for High-Temperature Flow, Heat Transfer, and Thermal Energy Storage with Applications in Advanced Small Modular Reactors, High Temperature Heat Exchangers, Hybrid Energy Systems, and Dynamic Grid Energy Storage Concepts," The Ohio State University, Dept. of Mechanical and Aerospace Engineering, Progress Report 2, Contract No. 42898, Release 35, August 2014.

40. Hayner, G. O., Bratton, R. L., Mizia, R. E., and Windes, W. E., "Next Generation Nuclear Plant Materials Research and Development Plan," INL/EXT-06-11701, Rev. 3, 2006.

41. Helicoflex Spring Energized Seals brochure, Technetics Group, EnPro Industries.

42. Heatric brochure, "Compact Diffusion-Bonded Heat Exchangers," 2014.

43. Hesselgreaves, J. E., Compact Heat Exchangers: Selection, Design and Operation, Pergamon Press, ISBN 0-08-042839-8, 2001.

44. Southall, D. and Deson, S. J., "Innovative Compact Heat Exchangers," Proceedings, ICAPP 2010, Paper No. 10300, pp. 218-226, San Diego, 2010.

45. Dewson, S. J., and Thonon, B., "The Development of High Efficiency Heat Exchangers for Helium Gas Cooled Reactors," Report No. 3213, International Conference on Advanced Nuclear Power Plants (ICAPP), Cordoba, Spain, 2003.

46. Cur, N., and Sparrow, E. M., "Measurements of Developing and Fully Developed Heat Transfer Coefficients along a Periodically Interrupted Surface," Journal of Heat Transfer, Vol. 101, No. 2, pp. 211-216, 1979.

47. O’Brien, J. E., "Corrugated-Duct Heat Transfer, Pressure Drop, and Flow Visualization," Journal of Heat Transfer, Vol. 104, No. 3, pp. 410-416, 1982.

48. Kato, Y., "Advanced High Temperature Gas-Cooled Reactor Systems," J. of Engineering for Gas Turbines and Power, Vol. 132, pp. 12902-1-7, 2010.

49. Sabharwall, P., Kim, E. S., McKellar, M., Anderson, N. A., and Patterson, M., "Process Heat Exchanger Options for Fluoride Salt High Temperature Reactor," INL/EXT-11-21584, Idaho National Laboratory, June 2011.

50. Holcomb, D. E., Ilas, D., Middleton, B., and Arrieta, M., "Small, Modular Advanced High-Temperature Reactor-Carbonate Thermochemical Cycle," ORNL/TM-2014/88, March 2014.

51. Shaffer, J. H., "Preparation and Handling of Salt Mixtures for the Molten Salt Reactor Experiment," ORNL-4616, Oak Ridge National Laboratory, January 1971.

52. Briggs, R. B., "Molten-Salt Reactor Program Semiannual Progress Report," ORNL-4037, Oak Ridge National Laboratory, July 31, 1964.

53. Kelleher, B. C., Sellers, S. R., Anderson, M. H., Sridharan, K., and Scheele, R. D., "Chemistry Control and Corrosion Mitigation of Heat Transfer Salts for the Fluoride Salt Reactor (FHR)," International Congress on Advances in Nuclear Power Plants 2012, ICAPP 2012, v 2, pp. 920-927, 2012. 
54. Scheele, R. D., and Casella, A. M., "Assessment of the Use of Nitrogen Trifluoride for Purifuing Coolant and Heat Transfer Salts in the Fluoride Salt-Cooled High-Temperature Reactor,"

PNNL-19793, Pacific Northwest National Laboratory, September 2010. 


\section{APPENDIX A \\ Subcontractor Report}

PRELIMINARY DESIGN ANALYSIS FOR THE INL ARTIST FACILITY Contract Administrative Data

Award Number:

Name of Recipient:

Project Title:

Principal Investigator:

Battelle Energy Alliance, LLC: Master Contract 42898, Release 35

The Ohio State University

Development of an INL Capability for High Temperature Flow, Heat Transfer, and Thermal Energy Storage with Applications in Advanced Small Modular Reactors, High Temperature Heat Exchangers, Hybrid Energy Systems, and Dynamic Grid Energy Storage Concepts

Associate Professor
Nuclear Engineering Program
E431 Scott Laboratory
The Ohio State University
201 W 19th Avenue
Columbus, OH 43210
Tel: 614-247-7646
Email: sun.200@osu.edu
Mr. Xiaoqin Zhang
Dr. Inhun Kim
Nuclear Engineering Program
The Ohio State University




\section{SUMMARY}

The overall goal of this subcontract is to support Idaho National Laboratory (INL) in developing a new, advanced, high-temperature, multi-fluid, multi-loop test facility aimed at investigating fluid flow and heat transfer, material corrosion, heat exchanger characteristics, and instrumentation performance, among other things, for nuclear applications. Specifically, preliminary research has been performed at the Ohio State University in conjunction with INL in the following areas:

1. A review of fluoride molten salts characteristics in thermal, corrosive, and compatibility performances. A recommendation for a salt selection is provided. Material candidates for both molten salt and helium flow loop have been identified.

2. A conceptual facility design that satisfies the multi-loop (two-coolant loops, i.e., fluoride molten salts and helium) multi-purpose (two operation modes, i.e., forced and natural circulation) requirements. Schematic models are presented. The thermal hydraulic performances in a preliminary printed circuit heat exchanger (PCHE) design have been estimated.

3. An introduction of computational methods and models for pipe heat loss analysis and cases studies. Recommendations on insulation material selection have been provided.

4. An analysis of pipe pressure rating and sizing. Preliminary recommendations on pipe size selection have been provided.

5. A review of molten fluoride salt preparation and chemistry control. An introduction to the experience from the Molten Salt Reactor Experiment at Oak Ridge National Laboratory has been provided.

6. A review of some instruments and components to be used in the facility. Flowmeters and Grayloc connectors have been included.

The work reported in the subcontract report presents conclusions drawn from the extensive review of literature in material selections and facility design progress at the current stage. It provides useful guidelines in insulation material and pipe-size selection, as well as an introductory review of facility process and components.

Note: The subcontractor report is available as INL/EXT-14-33562 